\title{
Components of School-Based Interventions Stimulating Students' Intrapersonal and Interpersonal Domains: A Meta-analysis
}

\author{
Esther Mertens $^{1}$ (D) Maja Deković ${ }^{1} \cdot$ Patty Leijten $^{2} \cdot$ Monique Van Londen $^{1} \cdot$ Ellen Reitz $^{1}$
}

Accepted: 21 September 2020 / Published online: 3 October 2020

(c) The Author(s) 2020

\begin{abstract}
Many universal school-based interventions aim to stimulate students' intrapersonal (e.g., self-esteem) and interpersonal (e.g., school climate) domains. To improve our understanding of why some of these interventions yield stronger effects than others, we identified intervention components that are related to stronger or weaker intervention effects. We systematically searched four databases (i.e., PsycINFO, PubMed, ERIC, CENTRAL) for controlled evaluations of universal school-based interventions. In total, 104 included studies (529 included effect sizes) reported on 99 unique interventions. Interventions showed small positive effects on the intrapersonal $(d=0.19)$ and interpersonal $(d=0.15)$ domains. Focusing on self-awareness and problem solving, using more active learning approaches, and using more extensive interventions predicted stronger intervention effects on aspects of both domains. In contrast, efforts to improve emotion regulation, assertiveness, cognitive coping, and using group discussions predicted weaker intervention effects. Furthermore, commonly implemented components were not necessarily related to stronger intervention effects and components that were related to stronger effects were not necessarily often implemented. Our findings highlight the need to carefully select components for inclusion in interventions. PROSPERO Registration Number: CRD42019137981.
\end{abstract}

Keywords Components $\cdot$ School-based intervention $\cdot$ Intrapersonal domain $\cdot$ Interpersonal domain $\cdot$ Students

\section{Introduction}

Schools are expected to foster not only their students' cognitive development, but also their students' wellbeing. Schools should implement policies and practices striving to improve students' attitudes, values, and social support (Langford et al. 2014; World Health Organization 1995). To this end, a range of universal school-based interventions have been developed to enhance students' intrapersonal and interpersonal domains. The intrapersonal domain refers to managing one's own feelings, emotions, and attitudes pertained to the individual self (Barber 2005). The interpersonal domain refers to the ability to build and maintain positive relationships with others and to understand social situations, roles, and norms, and respond appropriately (Pellegrino and Hilton

Esther Mertens

e.c.a.mertens@uu.nl

1 Utrecht University, Child and Adolescent Studies, Utrecht, The Netherlands

2 University of Amsterdam, Child Development and Education, Amsterdam, The Netherlands
2012; Shek and Leung 2016). Both domains are intertwined as the way individuals view themselves can influence how they approach social interactions and vice versa (Finkel and Vohs 2006).

Even though the two domains are related, they are also meaningfully distinct. While the intrapersonal domain represents an individual's subjective psychological functioning, the interpersonal domain represents an individual's social functioning (Dufner et al. 2019). This distinction is empirically supported by factor and profile analyses (e.g., Gilman and Anderman 2006; Park et al. 2017), and by relating the two domains to various developmental outcomes. For instance, competencies in the intrapersonal domain predict better academic achievement and competencies in the interpersonal domain predict better peer relations (Park et al. 2017). While students can acquire competencies in both domains by mastering relevant cognitive, affective, and social skills (Durlak et al. 2011), difficulties with these skills can set students at increased risk of developing problems in the intrapersonal domain, such as internalizing behavior, or in the interpersonal domain, such as aggression (Modecki et al. 2017; White et al. 2013). Given that competencies in 
both domains are markers of a healthy psychosocial development, whereas problems in these domains increase the likelihood of developing psychopathology later in life, it is important to stimulate youth's development in these domains (Van Order et al. 2005).

Children's intra- and interpersonal domains develop throughout their youth, but the importance of these skills becomes particularly pronounced in adolescence when they consolidate their own identity and peer relationships become increasingly important. Adolescents spend less time at home and longer hours at school which provides them increasing opportunities and requirements to interact with others, such as peers, teachers, and romantic partners (Barber 2005). This makes secondary school a potentially good target for interventions to foster youth's intra- and interpersonal domains. In the present meta-analysis, we therefore examined the effects of universal secondary school-based interventions on students' intrapersonal and interpersonal domains.

School-based interventions addressing adolescents' intraand interpersonal domains typically show small positive effects (e.g., effect sizes (Cohen's $d$ ) ranging from 0.03 to 0.24; Dray et al. 2017; Durlak et al. 2011; Jiménez-Barbero et al. 2016). One way to increase our understanding of when interventions are most effective is by studying which components are related to intervention effects. If we can identify components associated with stronger (or weaker) intervention effects, this could help generate hypotheses about the components that drive intervention effects, and thus about how interventions could be improved. In addition, schools can make informed decisions about which intervention to implement, by selecting interventions based on the evidence base for the components. As a first step towards generating hypotheses about components that drive intervention effects, Boustani et al. (2015) listed components that are most frequently included in effective school-based interventions (e.g., problem solving, psychoeducation). Although such a frequency count provides a useful overview, it does not show whether the effectiveness of interventions relates to the presence of the components. Furthermore, due to the focus on effective interventions, the overview cannot identify components related to weaker intervention effects. The present meta-analysis statistically tested which components are related to stronger or weaker intervention effects.

In the literature, typically three types of components are distinguished: Content, instructional, and structural components. Content components are specific skills adolescents learn to promote positive outcomes, such as emotion regulation and problem solving (Boustani et al. 2015), i.e., "what they learn." Instructional components are techniques and methods of information delivery used by the intervention facilitator, such as cognitive restructuring and modeling (Boustani et al. 2015), i.e., "how they learn it." Structural components describe the structure of the intervention that might impact results, such as the number of sessions and whether or not parents are included in the intervention (Lee et al. 2014), i.e., "how the intervention is set up." By examining all three types of components, we strive to improve our understanding of whether a certain type of component is particularly associated with intervention effects.

Various meta-analyses have successfully identified intervention components that predict intervention effects (e.g., De Mooij et al. 2020; De Vries et al. 2015; Kaminski et al. 2008; Van der Put et al. 2018), but few meta-analyses have focused on components of school-based interventions. Prior meta-analyses that did examine components of school-based interventions focused on substance use, sexual risk behaviors (e.g., pregnancy, STD/HIV) and/or nutrition (see for a review of reviews Peters et al. 2009). For example, Onrust et al. (2016), focusing on substance use, found that components that sought to stimulate students' self-control and problem solving, and components that included cognitive restructuring, adjusting social norms (e.g., peer education), and parental involvement predicted stronger substance use reductions. Hennessy and Tanner-Smith (2015), focusing on alcohol use, found that components that included an individual and motivational enhancement approach predicted stronger alcohol use reduction.

In the present meta-analysis, we examined which components are related to stronger (or weaker) school-based intervention effects on students' intra- and interpersonal domains. We focused on a broad range of outcomes for two reasons. First, many school-based interventions aim to enhance multiple aspects of students' development (e.g., promoting self-efficacy, psychological wellbeing, and life satisfaction: Gigantesco et al. 2015; bullying, aggression, and wellbeing across various domains: Bonell et al. 2018). We wanted to align with this approach in our meta-analysis. Second, some components may be related to intervention effects on some outcomes, but not on others. Unraveling these differential associations may provide insight in the extent to which interventions need to be matched to specific problems.

We studied relations between components and intervention effects across different populations (e.g., socio-economically advantaged students, predominately ethnic minority students). Although the effectiveness of components may depend on participant characteristics, any moderator effects by participant characteristics were beyond the scope of this study - our goal was to provide a first overview of which components are related to intervention effects. We analyzed all three types of components (i.e., content, instructional, and structural) and tested whether interventions with a specific component showed larger (or smaller) effect sizes than interventions without that component, using multilevel meta-regression. This enabled us to identify not only which components were associated with stronger effects, suggesting potential effective components, but also components 
associated with weaker effects, suggesting potential ineffective components. Knowing what does not work is equally important as knowing what does work (e.g., Poulin et al. 2001; Werch and Owen 2002).

Concerning content components, based on the results of Onrust et al. (2016) and Boustani et al. (2015), we hypothesized that basic life skills and self-awareness would be related to stronger intervention effects on students' intraand interpersonal domains. Basic life skills refers to abilities for adaptive and positive behavior to deal with demands and challenges of everyday life (World Health Organization 1997). Several reviews suggest the importance of basic life skills, such as problem solving, assertiveness, and social skills, for a range of outcomes of effective schoolbased interventions (e.g., intra- and interpersonal domains, Boustani et al. 2015; drug use, Cuijpers 2002). Self-awareness indicates a realistic and accurate assessment of one's strengths and norms, and is related to improvements on the interpersonal domain (e.g., Shek and Leung 2016). Raising self-awareness, such as insight building and self-efficacy, is often used in effective interventions targeting the intrapersonal and interpersonal domains (Boustani et al. 2015).

For instructional components, we hypothesized that components using a more active learning approach, in which students interact with each other and perform tasks (e.g., practicing through role-play), would be related to stronger intervention effects. Active learning approaches have consistently been related to stronger effects. For instance, Kaminski et al. (2008) found in their meta-analysis that parenting interventions in which parents practiced the learned skills were more effective than interventions that did not include practice. Similarly, Cuijpers (2002) concluded in his review of school-based drug interventions that interventions using more active methods (e.g., discussion) were more effective than interventions using more passive methods (e.g., didactic instruction).

Regarding structural components, the general assumption is that longer and extensive interventions are more effective than briefer and less extensive interventions (Yeager and Walton 2011). The evidence, however, is conflicted. Some meta-analyses showed that longer and extensive interventions are indeed more effective. For instance, interventions showed stronger effects as the time span, number of sessions, and involved persons (i.e., whole school, parents) increased (De Vries et al. 2015; Ttofi and Farrington 2011). Other meta-analyses, on the other hand, showed that briefer and less extensive interventions are more effective (i.e., "less is more"). For instance, interventions showed stronger effects when the time span was short, the number of sessions limited, and no additional services were provided (Cuijpers 2002; Kaminski et al. 2008; Van der Put et al. 2018). Longer and extensive interventions require more time and effort to implement with fidelity (Bakermans-Kranenburg et al. 2003); resources that may lack in many schools. Given that findings of previous research concerning structural components are inconclusive, examining the relations between these components and intervention effects was explorative.

In summary, identifying components related to stronger or weaker intervention effects has both theoretical and practical implications. First, it expands our knowledge concerning interventions. We begin to unravel, based on associations between components and intervention effects, what is more important to change students' intra- and interpersonal domains: What they learn, how they learn it, or how the intervention is set up? Second, it helps schools to make informed decisions about which intervention to implement and catalyzes hypotheses generation about how interventions may be optimized. We hope this knowledge can be used as a first step towards improving the effectiveness of school-based interventions addressing students' intra- and interpersonal domains.

\section{Method}

\section{Inclusion and Exclusion Criteria}

We sought to include evaluations of universal secondary school-based interventions addressing students' intrapersonal and interpersonal domains. Universal secondary school-based interventions were defined as interventions delivered to students during regular school hours, targeting all students (Mychailyszyn et al. 2012; Peters et al. 2009). The intrapersonal domain was defined as managing one's own feelings, emotions, and attitudes pertained to the individual self (Barber 2005) in which one can experience competencies (e.g., resilience, self-esteem, self-regulation, general wellbeing) and problems (e.g., internalizing behavior). The interpersonal domain was defined as the ability of an individual to build and maintain positive relationships with others and understanding social situations, roles and norms, and respond appropriately (Pellegrino and Hilton 2012; Shek and Leung 2016) in which one can experience competencies (e.g., sexual health, social competence, positive school climate) and problems (e.g., aggression, bullying). Although one's development in these two domains has been associated with psychopathology, the domains and psychopathology are not opposite ends of the same continuum (e.g., Girard et al. 2017). In the current meta-analysis, we focused on interventions stimulating the development in the intra- and interpersonal domains rather than preventing psychopathology.

Studies were eligible for review when (1) the intervention was implemented in a regular school (i.e., not in special education), (2) the intervention was implemented during regular school hours in a group setting, (3) the intervention was aimed at improving (subdomains of) the intra- and/or interpersonal domain (i.e., interventions primarily aiming 
to improve students' physical health (e.g., prevention of substance use, nutrition, pregnancy, STDs) or prevent psychopathology (e.g., depression) were excluded.), (4) the intervention was universal, so targeting all students, (5) the participants were in middle school or high school (Grades 6-12), (6) the study included a control group, (7) the study included a quantitative baseline and post intervention measurement of (subdomains of) the intrapersonal domain and/or interpersonal domain, (8) sufficient information concerning baseline and post intervention measurements was reported, or obtained after contact with the author, so that effect sizes could be calculated post intervention, corrected for baseline differences, (9) the study was written in English, and (10) the study was published as article, book, or book chapter. Research has shown that including unpublished studies does not reduce the possible impact of publication bias and is sometimes even counterproductive due to selection bias (Ferguson and Brannick 2012).

\section{Literature Search}

We searched four databases (i.e., PsycINFO, PubMed, ERIC, and CENTRAL). With these databases we searched the psychological, medical, and educational literature, and (quasi-)randomized controlled trials specifically. The search was not restricted to a time period. Search terms were used to elicit school-based interventions (e.g., school, class), interventions (e.g., prevention, intervention), adolescents (e.g., adolescent, youth), and intra- and interpersonal outcomes (e.g., self-esteem, social competence). Because these search terms led to an extremely high number of studies, we added some restrictions to the search, to avoid picking up interventions targeting other populations (e.g., preschool, clinical) or domains (e.g., substance use, lifestyle) than targeted in this study. The complete list of search terms is provided in "Appendix A". This search (April 2019) resulted in 6102 studies in PsycINFO, 2964 studies in PubMed, 1683 studies in ERIC, and 567 studies in CENTRAL. Removal of duplicates resulted in 9,498 unique studies. In addition, reference lists of included studies and identified relevant reviews and meta-analyses were searched. This resulted in 22 additional studies.

All studies identified by the search were first screened for eligibility based on their title and abstract. Title and abstract were reviewed to assess whether the study met inclusion and/ or exclusion criteria. We specifically focused on information where the intervention was conducted (e.g., school-based), at what type of school the intervention was conducted (e.g., middle/high school), and whether the intervention was implemented during regular school hours (rather than after school). Based on this screening 9,068 studies (95\%) were excluded. The remaining 429 studies were studied full-text.
In this second screening phase another 310 studies (72\%) were excluded. See Fig. 1 for the flow diagram.

In order to assess reliability of these two screening phases, a research assistant independently screened a random selection of $9 \%$ (800 studies) of all identified studies concerning the first screening phase and in the second screening phase $10 \%$ (45 studies) of the remaining studies. The research assistant judged the relevance of the studies for the current meta-analysis based on the inclusion and exclusion criteria. Reliability was substantial, with $98 \%$ agreement (Cohen's $\kappa=0.71$; Landis and Koch 1977) regarding the first screening phase and $89 \%$ agreement (Cohen's $\kappa=0.76$; Landis and Koch 1977) regarding the second screening phase. Any disagreements between the researchers concerning inclusion were solved through discussion.

\section{Data Extraction}

Studies were coded for information concerning the study (e.g., year of publication, country where study was conducted), sample (e.g., age, gender distribution), design and method (e.g., randomization, attrition analyses), intervention (e.g., intervention provider, aim of intervention), effect size data (e.g., outcome category), and intervention components (e.g., problem solving, practice, parental involvement). The intervention components were primarily based on the metaanalysis by Boustani et al. (2015) who, in turn, based their components on the PracticeWise Clinical Coding System (PracticeWise 2009). Additionally, we reviewed the components of the reviews and meta-analyses of Kaminski et al. (2008), Onrust et al. (2016), Peters et al. (2009), and Van der Put et al. (2018) to further strengthen the theoretical base of the components. Based on this broad theoretical basis, we adjusted some components of Boustani et al. (2015) due to highly overlapping content and co-occurrence (i.e., we combined communication skills and social skills; we combined cognitive coping and coping skills; emotion regulation contains anger management; practice contains role-play) and we deleted some components due to low frequency (i.e., civic responsibility, support networking). An overview of all components and their definitions is presented in "Appendix B". Sources cited in the study and other freely available materials, such as descriptions from the developer or websites, were retrieved for coding the components (Boustani et al. 2015; Kaminski et al. 2008). In cases where insufficient data were reported for calculating the effect size, the first author was contacted. When this author had not responded after a reminder, the second or last author was contacted and, if necessary, reminded. If the required data could not be obtained after this, the study was excluded from the metaanalysis (see Fig. 1 for the flow diagram).

Of the included studies, 28\% (30 studies) was coded independently by a second coder for reliability. The inter-rater 
Fig. 1 Flow diagram

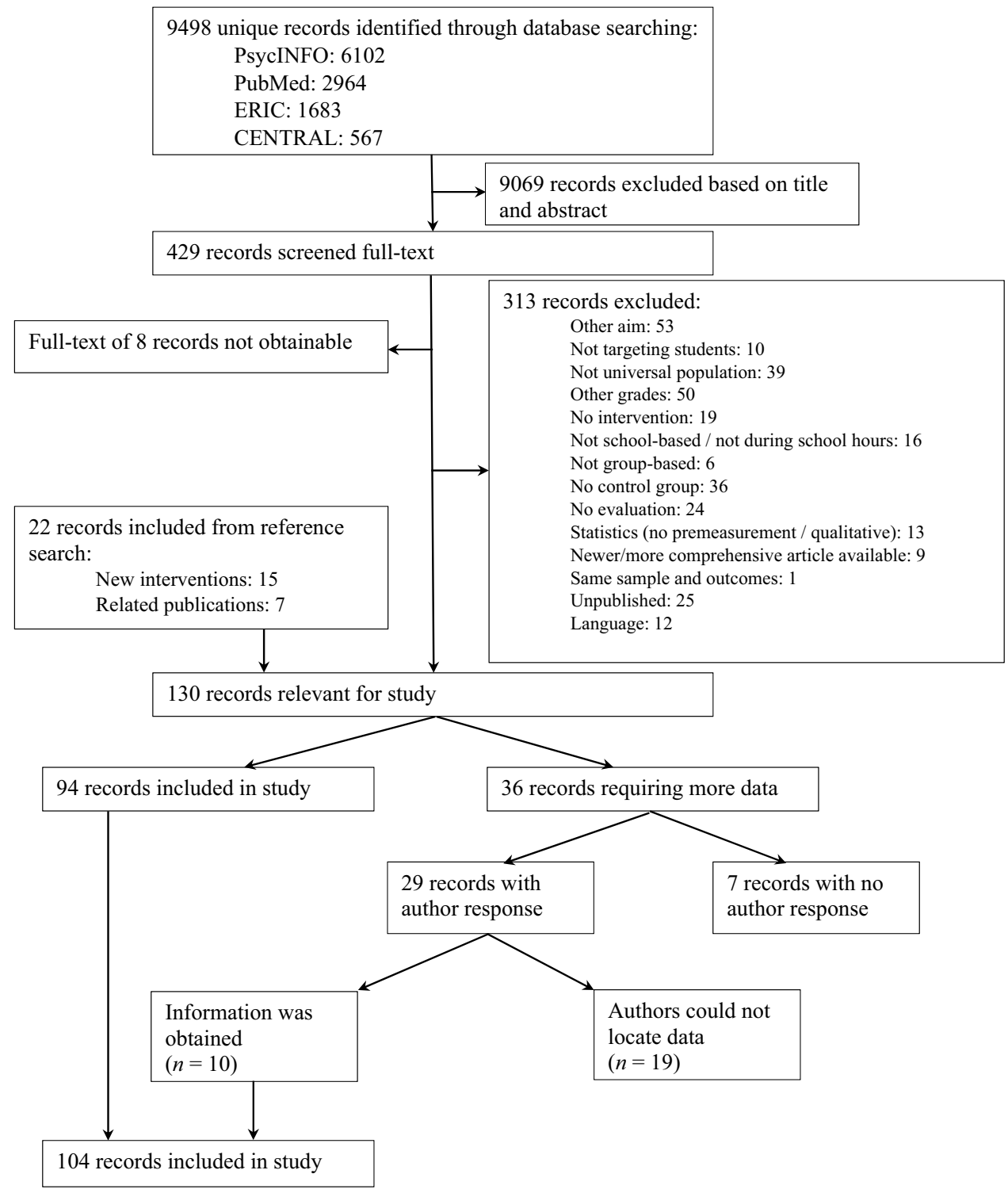

reliability was moderate to excellent (Landis and Koch 1977) with an average intra-class-correlation of $0.97(\mathrm{SD}=0.05)$, ranging from 0.88 to 1.00 , for continuous variables, and an average Cohen's kappa of $0.82(\mathrm{SD}=0.11)$, ranging from 0.60 to 1.00 , for categorical variables (see "Appendix C" for the reliability per individual code). Coding of the component 'Insight building' was not reliable with Cohen's kappa of 0.52. Disagreements between the two coders were discussed and solved unanimously.

\section{Calculation and Analyses of Effect Sizes}

Effect sizes were represented as Cohen's $d$, reflecting the standardized mean difference between the intervention and control condition, following the procedures of Lipsey and Wilson (2001):
Cohen's $d=\frac{\bar{X}_{G 1}-\bar{X}_{G 2}}{s_{p}}$

Effect sizes were calculated at post intervention (i.e., within 6 months after the intervention) and corrected for baseline differences. Positive effect sizes indicated better results for the intervention compared to the control condition. All effect sizes were adjusted using the Hedges' (1983) small sample correction prior to analyses:

Hedges' adjusted effect size $=d *\left(1-\frac{3}{4 N-9}\right)$

Outliers were examined and, when believed to be unrepresentative, winsorized by replacing outliers with the value of the lower or upper value of two standard deviants from the mean (Lipsey and Wilson 2001). 


\section{Publication Bias}

As commonly known, studies with nonsignificant or negative results are less likely to be published than studies with significant or positive results. The risk of publication bias was tested using a funnel plot. A funnel plot is a scatter plot in which the effect sizes are plotted against their precision (i.e., standard error). It is assumed that the effect sizes of the studies are symmetrically distributed around the true effect size, with more precise effect sizes (typically those from larger studies) at the top of the funnel and less precise effect sizes (typically those from smaller studies) at the base of the funnel. Asymmetry in the funnel plot can be an indication of publication bias (Light and Pillemer 1984). Whether or not a funnel plot is asymmetrical can be statistically tested with Egger's regression test (Egger et al. 1997). When the funnel plot is asymmetrical according to Egger's regression test the trim-and-fill analysis (Duval and Tweedie 2000a, 2000b) can be used to adjust the effect for possible publication bias. This analysis estimates how many studies fall outside the symmetric part of the funnel plot and trims this outlying part. With the remaining symmetric funnel plot the true center of the funnel is estimated. The trimmed studies and their missing counterparts are replaced in the funnel representing imputed 'missing' effect sizes. Based on this filled funnel plot, the corrected mean is estimated resulting in an adjusted effect size. Tests to visualize and examine publication bias assume independence of effect sizes, which is not the case in multilevel meta-analyses. We took this violation into account by using the variance of the effect sizes as a moderator in Egger's regression test.

\section{Analyses}

We calculated an effect size for each reported measure of the intra- or interpersonal domain. To account for the clustering of effect sizes within a trial, we used multilevel meta-analytical models with three levels: Sampling variance around each effect size (level 1), variance between effect sizes within studies (level 2), and variance between studies (level 3; Assink and Wibbelink 2016; Van den Noortgate et al. 2013).

The unit of analyses were the interventions rather than the publications, since we are interested in the effectiveness of the intervention compared to the control condition. When one publication reported on two interventions, both interventions were included and analyzed separately. When multiple publications reported on the same intervention, evaluated in different studies with different samples, their effect sizes were analyzed together, clustered within the same intervention. When multiple publications reported on the same intervention, evaluated in the same study with the same sample, we coded the most comprehensive publication; the less comprehensive publication was checked for additional information and their effect sizes were analyzed together, clustered within the same intervention.

The multilevel analyses were conducted in $\mathrm{R}$ using the metaphor package (Viechtbauer 2010). First, the overall effects of universal school-based interventions on students' intrapersonal and interpersonal domains were estimated in separate models. Methodological rigor was assessed to examine how well the overall effect sizes reflected the effects of the intervention rather than methodological influences or biases (Lipsey and Wilson 2001). Based on the Cochrane Risk of Bias 2.0 tool for Cluster Randomized Trials (Higgins et al. 2016) randomization (random vs. quasi-random assignment) and completeness of outcome data (percentage of drop-out) were analyzed as covariates. Additionally, the type of comparison group (passive: No intervention/waitlist vs. active: Care as usual/other intervention) was examined as covariate to examine absolute versus relative effects of the interventions. Characteristics of methodological rigor that predicted the overall effect sizes were included as covariates in further analyses.

To analyze which components were associated with stronger or weaker intervention effects, moderation analyses were conducted. Moderation analyses were conducted only if both levels of the moderator (i.e., component present or not) contained at least three effect sizes (Crocetti 2016). Note that these moderation analyses are based on correlations between interventions and effects. Besides significant effects $(p<0.05)$, effects with a trend towards significance $(p<0.10)$ were reported. These trends contribute to the hypotheses generation nature of the meta-analysis and provide an indication to what extent moderation by a certain component for a certain outcome can be generalized to other outcomes.

\section{Results}

\section{Descriptive Characteristics}

The present meta-analysis included 104 publications reporting on 99 unique interventions. In total, 529 effect sizes were extracted from the publications comparing the intervention with the control condition on the intrapersonal domain $(k=218)$ or the interpersonal domain $(k=311)$. Four effect sizes were extreme outliers, more than four standard deviations above the mean. All were derived from the same study (Haynes and Avery 1979) and believed to be unrepresentatively high. These four effect sizes were therefore winsorized.

The studies, published between 1979 and 2019 (Median publication year: 2013), were conducted in the USA $(k=36)$, Canada $(k=2)$, Europe $(k=45)$, Australia $(k=7)$, Asia $(k=13)$, and Africa $(k=1)$. Most studies randomly 
assigned participants to the conditions $(k=70)$. In 47 studies, the intervention group was compared to an active control group (i.e., Care As Usual or another intervention). The other 57 studies compared the intervention group to a passive control group (i.e., waitlist or no intervention). In total, the studies comprised 97,884 participants with an average age of 13.70 years $(\mathrm{SD}=1.50)$ at the start of the intervention and mean sex distribution of $49 \%$ boys $(\mathrm{SD}=16.43)$. Of the studies reporting ethnicity $(59 \%)$, participants represented mostly ethnic majority in $59 \%$ of the studies, mostly ethnic minorities in $28 \%$ of the studies, and mixed ethnic majority and minorities in $13 \%$ of the studies. The mean drop-out rate of participants was $12.33 \%(\mathrm{SD}=10.65)$. The interventions consisted on average of 14 sessions $(\mathrm{SD}=15.35)$ with a time span of 22.55 weeks $(\mathrm{SD}=33.59)$. Roughly half of the interventions were provided by teachers $(k=46)$ and the other half

Table 1 Effectiveness of interventions targeting the intra- and interpersonal domains

\begin{tabular}{llll}
\hline Domains & Effect sizes $(k)$ & Effect size & $95 \%$ CI \\
\hline Intrapersonal & 218 & 0.19 & $0.13 ; 0.25$ \\
Resilience & 13 & 0.06 & $-0.01 ; 0.14$ \\
Self-esteem & 53 & 0.25 & $0.11 ; 0.39$ \\
Self-regulation & 33 & 0.21 & $0.08 ; 0.33$ \\
General wellbeing & 63 & 0.13 & $0.08 ; 0.19$ \\
Internalizing problems & 50 & 0.19 & $0.10 ; 0.29$ \\
Interpersonal & 311 & 0.15 & $0.10 ; 0.19$ \\
Sexual health & 61 & 0.16 & $0.07 ; 0.26$ \\
Social competence & 63 & 0.16 & $0.10 ; 0.23$ \\
School climate & 17 & 0.24 & $-0.11 ; 0.58$ \\
Aggression & 84 & 0.10 & $0.03 ; 0.17$ \\
Bullying & 82 & 0.13 & $0.03 ; 0.24$ \\
\hline
\end{tabular}

$(k=58)$ by professionals. In addition, in 6 interventions the intervention was (also) provided by a peer. "Appendix D" provides the key characteristics of the included studies.

\section{Overall Effect Sizes}

Interventions had a small positive effect on students' intrapersonal domain $[d=0.19,95 \%$ CI $(0.13 ; 0.25)]$. More specifically, the positive intervention effects for selfesteem and self-regulation were somewhat stronger than for internalizing problems and wellbeing. No significant intervention effect was found for resilience (see Table 1). Interventions also had a small positive effect on students' interpersonal domain $[d=0.15,95 \%$ CI $(0.10 ; 0.19)]$. The magnitude of intervention effects was fairly similar for aggression, sexual health, social competence, and bullying. Interventions showed the strongest positive effects on school climate. However, this effect did not reach significance due to the small number of effect sizes for this subdomain. Definitions of the two general domains and the subdomains are provided in "Appendix E".

\section{Publication Bias}

For both the intra- and interpersonal domains, the distribution of effect sizes appeared to be symmetrical (Egger's regression test: Intrapersonal $z=-0.22, p=0.826$; Interpersonal $z=0.17, p=0.862$; see Fig. 2), indicating that there was low risk of publication bias.
Fig. 2 Funnel plot of effect sizes concerning the intrapersonal (left) and interpersonal (right) domains
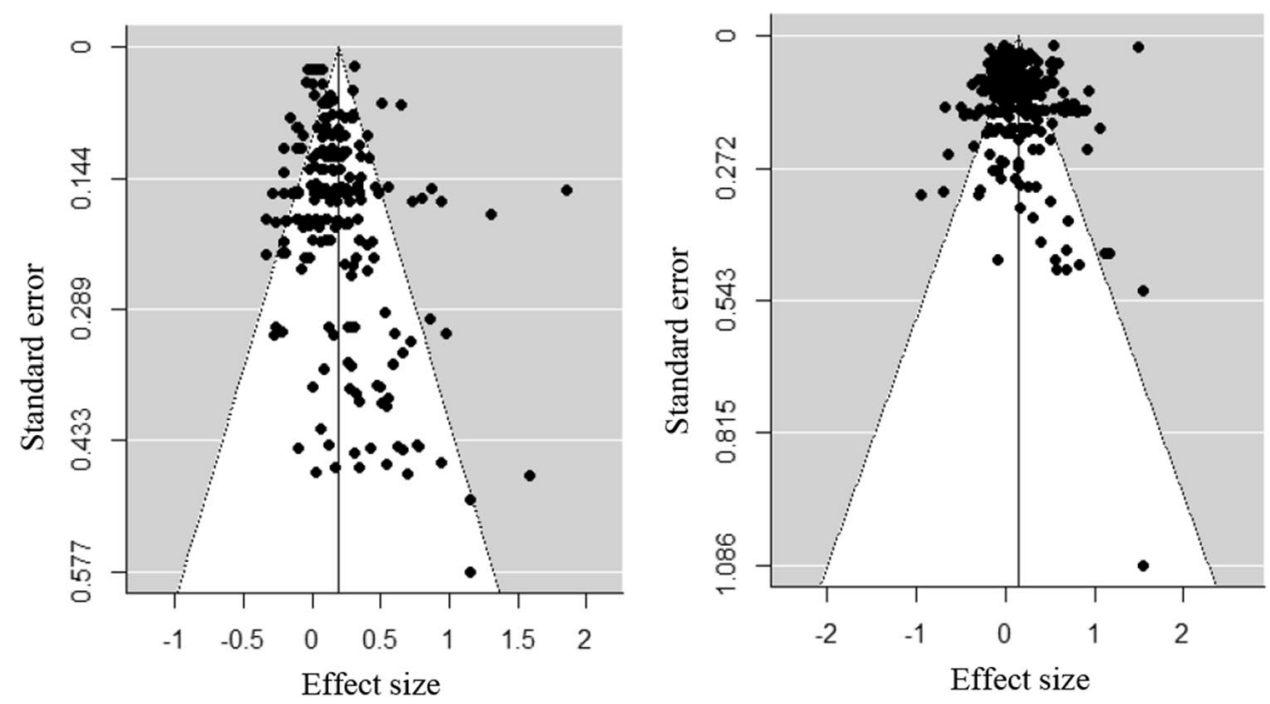


\section{Intervention Components Related to Intervention Effects}

\section{Preliminary Analyses}

Interventions targeting students' intrapersonal domain (see Fig. 3) and those targeting students' interpersonal domain (see Fig. 4) shared many commonly used components. Most commonly used content components are teaching students social skills, emotion regulation, and insight building. Most commonly used instructional components are implementing discussions, practice, and didactic instruction. The most commonly used structural component is additional individual guidance during the intervention.

Concerning methodological rigor, whether or not participants were randomized, drop-out rate, and type of comparison group were not related to effect sizes concerning the intrapersonal domain or the subdomains. Whether or not participants were randomized was related to effect sizes concerning the interpersonal domain; randomized studies yielded stronger effects. Percentage of drop-out was related to effect sizes concerning social competence; studies with lower drop-out rates yielded stronger effects. Whether or not participants were randomized and drop-out rates were also related to effect sizes concerning bullying; randomized studies and higher drop-out rates yielded stronger effects. Therefore, randomization and drop-out were added as covariates when it were significant predictors of the effect size in the moderation analyses concerning the interpersonal domain, social competence, and bullying.

\section{Intrapersonal Domain}

Of the ten content components, none were significantly related to intervention effects on students' intrapersonal domain in general (see Table 2). However, there was a trend that teaching emotion regulation was associated with weaker intervention effects on the intrapersonal domain overall, and
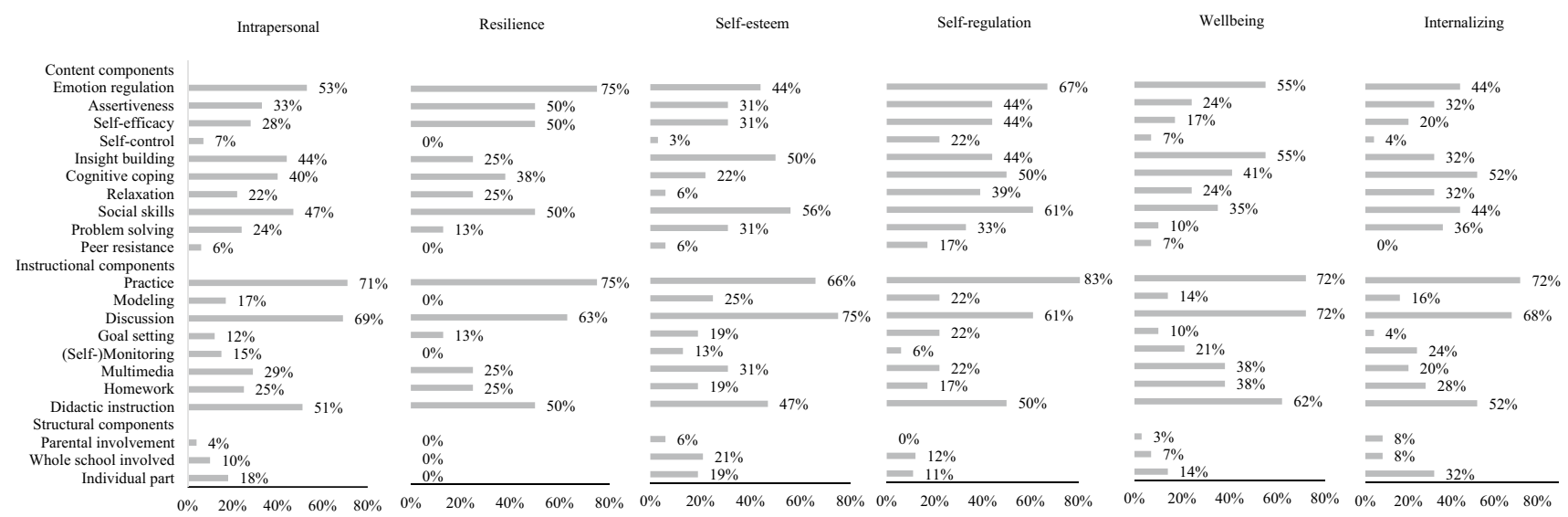

Fig. 3 Frequencies of components applied in interventions targeting the intrapersonal domain and subdomains

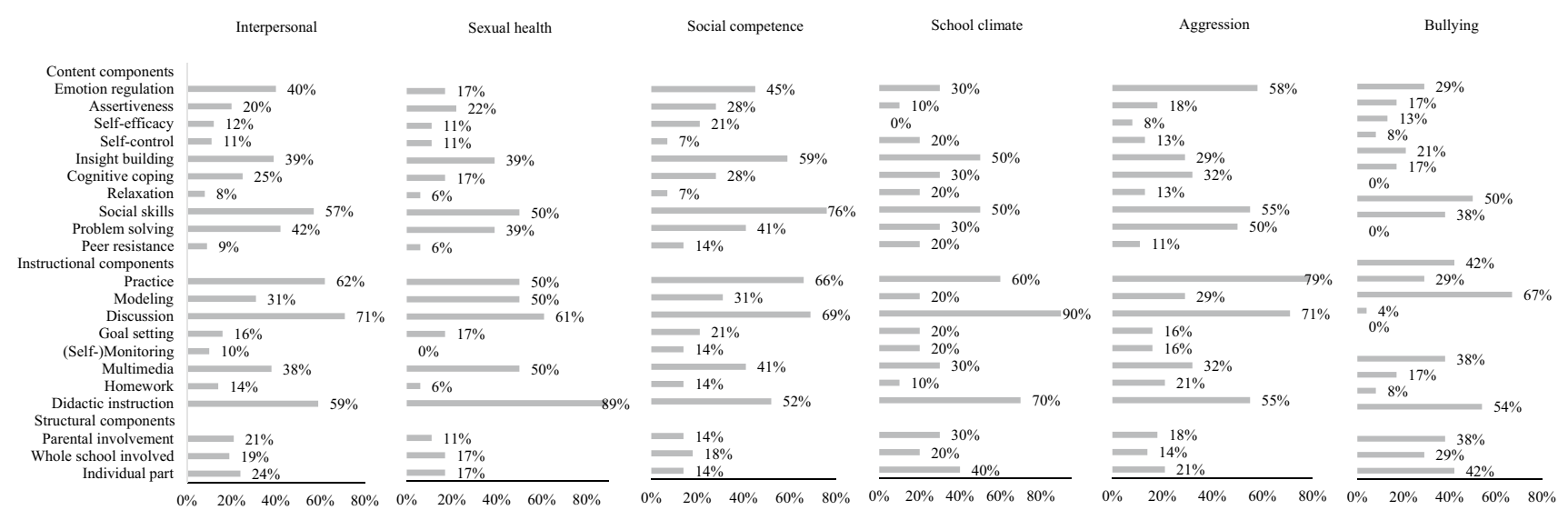

Fig. 4 Frequencies of components applied in interventions targeting the interpersonal domain and subdomains 


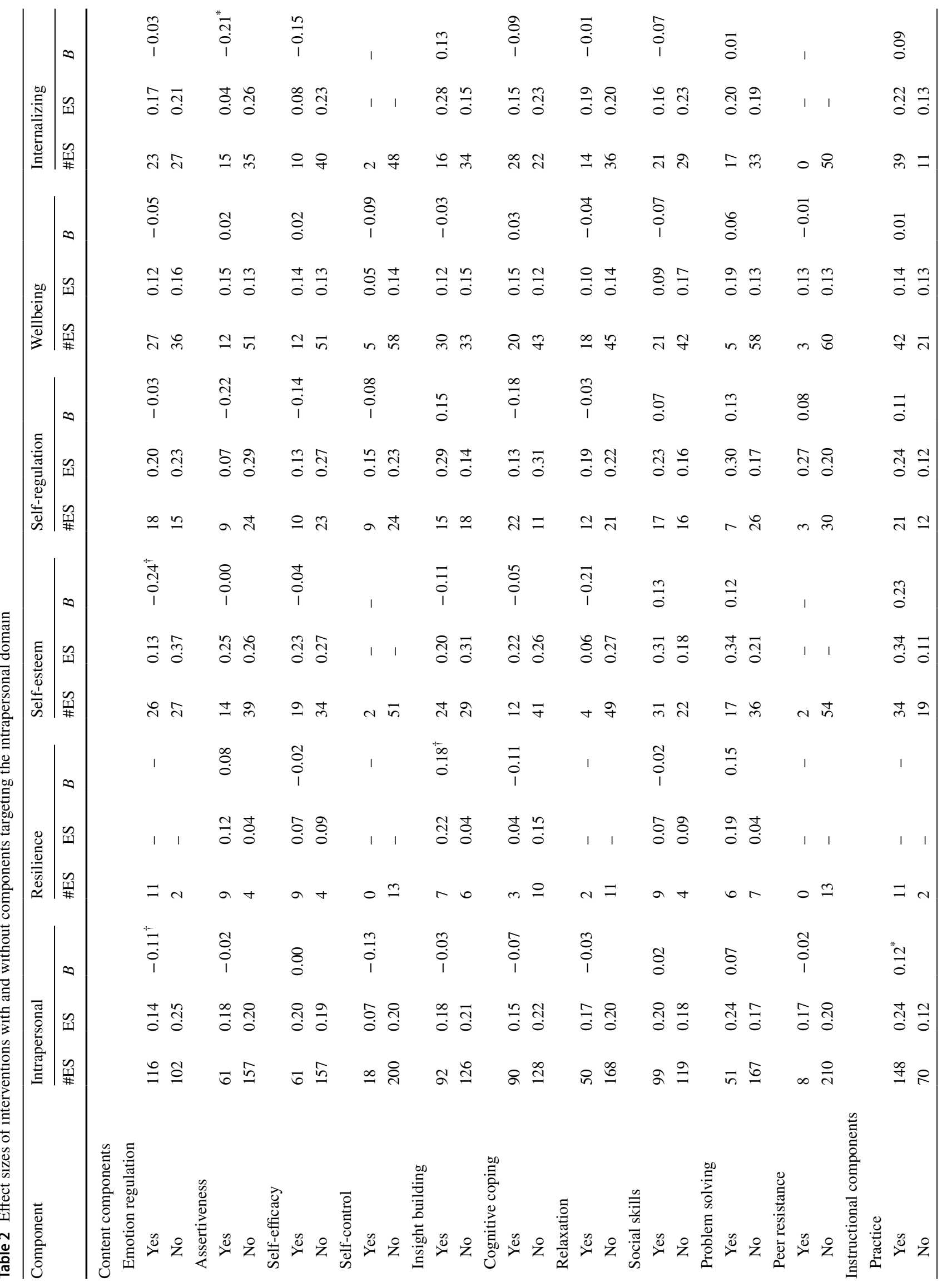


614

Clinical Child and Family Psychology Review (2020) 23:605-631

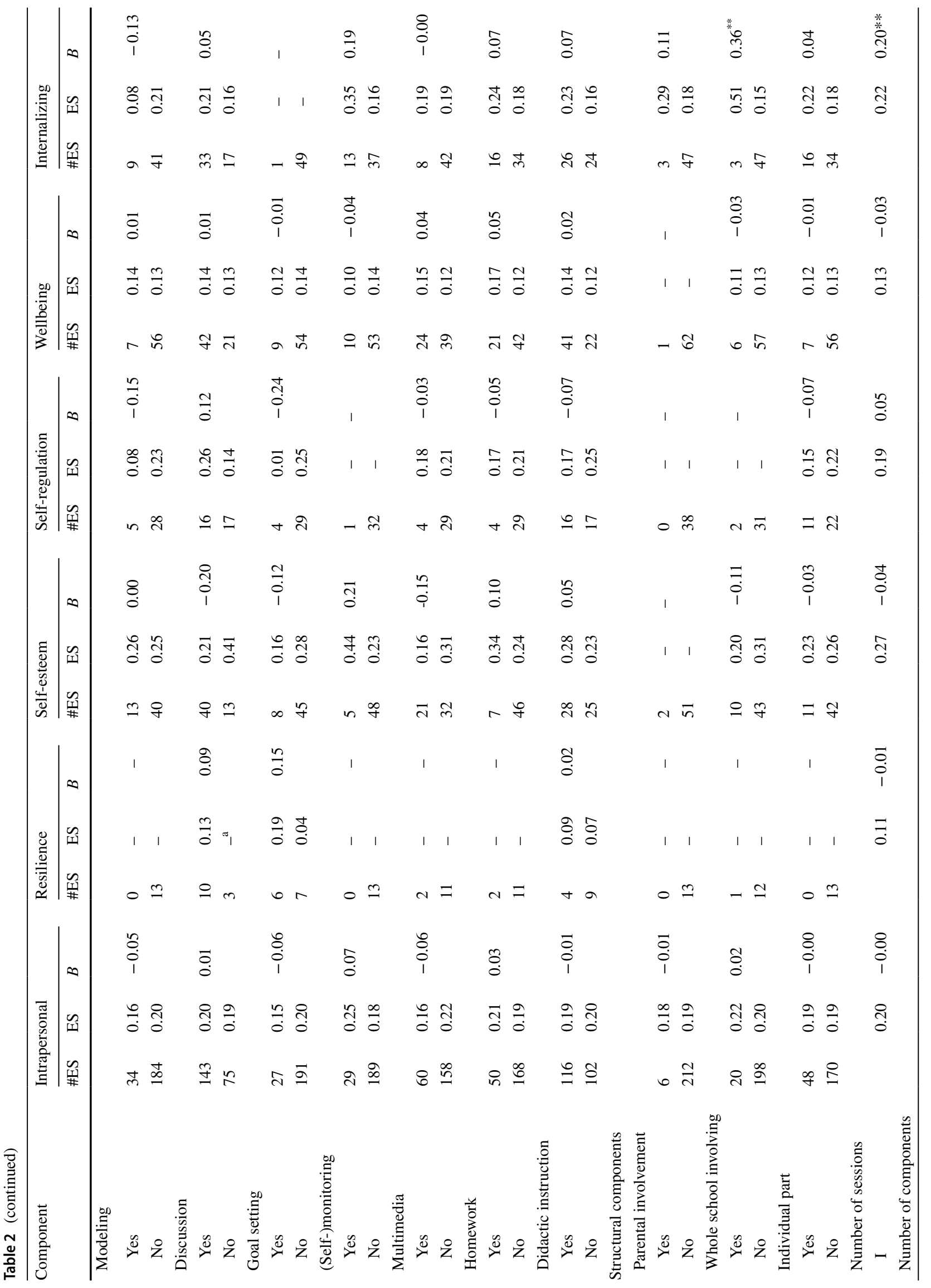

Springer 
specifically on self-esteem. For the subdomains, teaching assertiveness was associated with weaker effects on internalizing problems. Furthermore, there was a trend that insight building was associated with stronger effects on resilience.

Of the eight instructional components, practicing during the intervention was related to significantly stronger intervention effects on students' intrapersonal domain overall. None of the other components were significantly related to intervention effects on students' intrapersonal domain in general.

Of the five structural components, none were related to intervention effects on students' intrapersonal domain in general. For the subdomains, associations with stronger effects were found on internalizing problems when the whole school was involved and when the intervention had more sessions.

In sum, interventions that included insight building, where students practiced during the sessions, that involved the whole school staff, and those that had more sessions showed stronger effects for stimulating subdomains of the intrapersonal domain than interventions that did not include these components. Interventions that taught emotion regulation and assertiveness showed weaker effects for stimulating subdomains of the intrapersonal domain than interventions that did not include these components.

\section{Interpersonal Domain}

Of the ten content components, teaching problem solving was related to stronger intervention effects on students' interpersonal domain in general, specifically for interventions targeting bullying and school climate (see Table 3). Teaching cognitive coping was related to weaker intervention effects on students' interpersonal domain overall, and specifically for interventions targeting bullying. Furthermore, there was a trend that insight building was associated with stronger intervention effects on students' interpersonal domain overall. The other components were not related to intervention effects on the interpersonal domain in general. For the subdomains, insight building was associated with stronger effects on social competence and bullying. Teaching emotion regulation and assertiveness were associated with weaker effects on respectively bullying and aggression.

Of the eight instructional components, none of the components were related to intervention effects on the interpersonal domain in general. Regarding the subdomains, using multimedia was related to stronger effects on social competence. In addition, there were trends that using didactic instruction and relaxation were associated with stronger effects and using discussion had weaker effects on aggression.

Of the five structural components, none were related to intervention effects on students' interpersonal domain in 


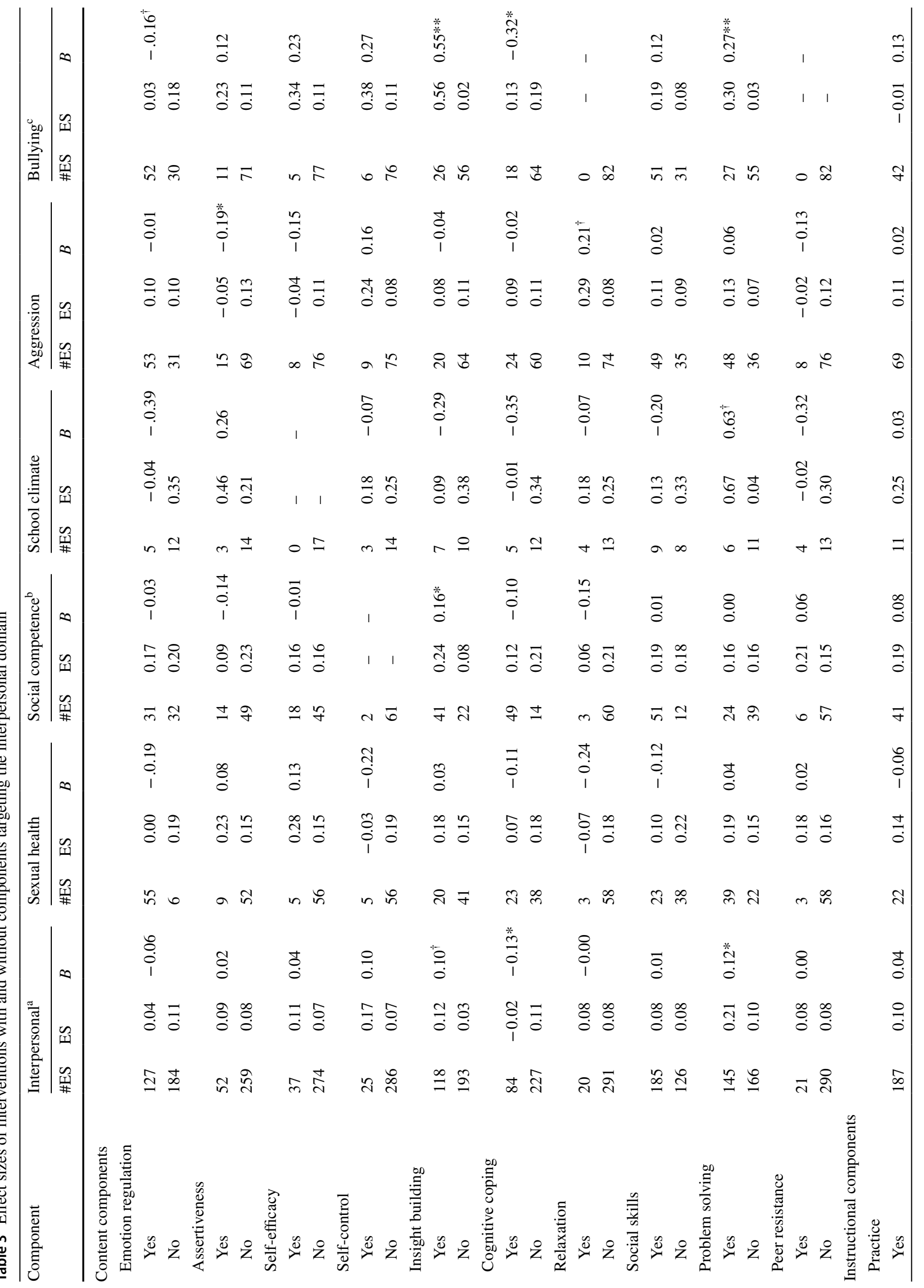




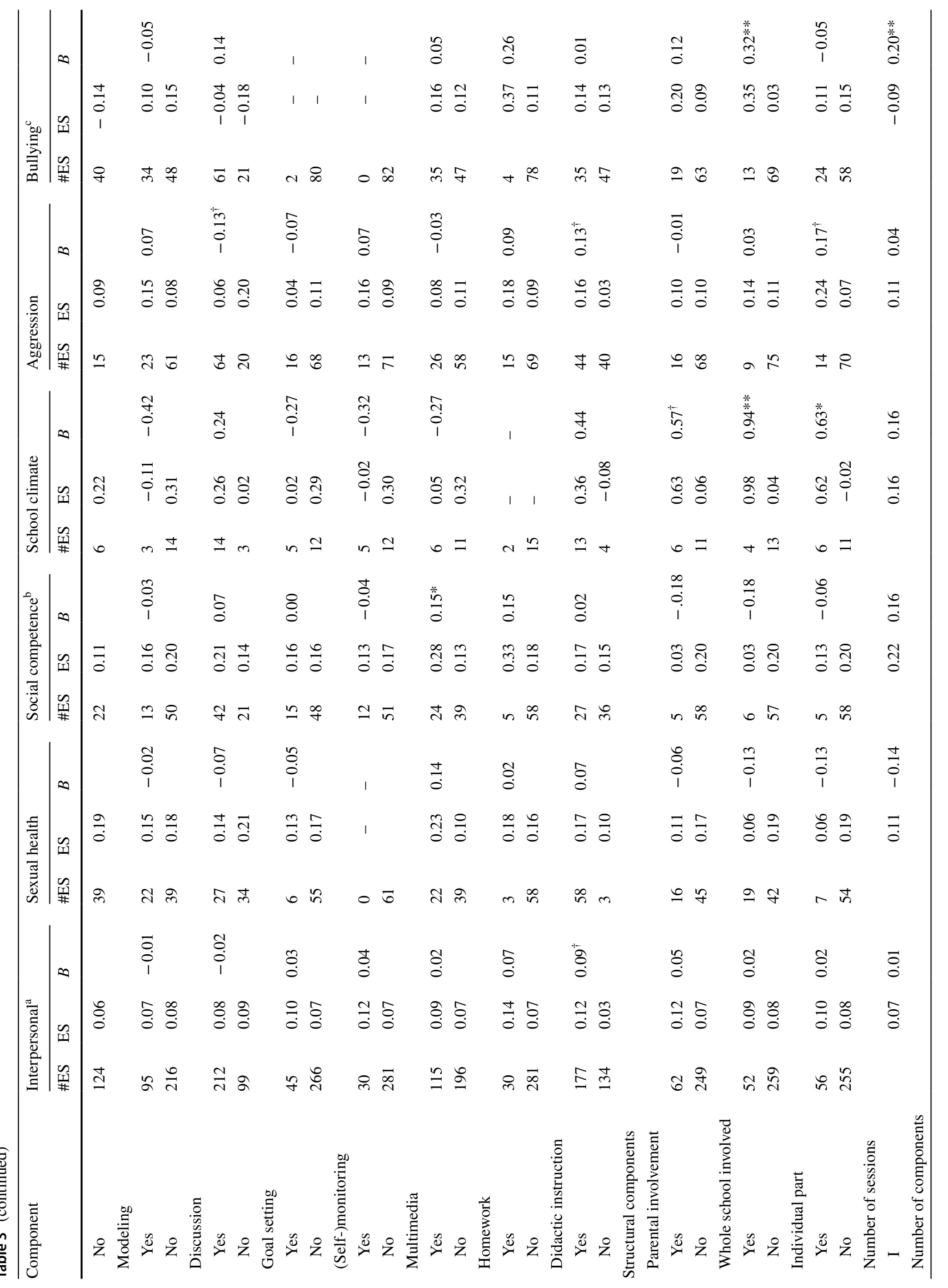


general. Concerning the subdomains, three components were related to stronger intervention effects. Interventions that included more sessions were associated with stronger effects on bullying. Interventions that involved the whole school were associated with stronger effects on bullying and school climate. Interventions with additional individual guidance were associated with stronger effects on school climate and showed a trend that it was related to stronger effects on aggression. Furthermore, there was a trend that interventions that involved parents were associated with stronger effects on school climate and that interventions that included more components were related to stronger effects on bullying.

In sum, interventions that taught insight building, and problem solving, used didactic instruction, relaxation, and multimedia, involved the whole school and parents, included additional individual guidance, more sessions, and more components showed stronger intervention effects for stimulating subdomains of the interpersonal domain than interventions that did not include these components. Interventions that taught emotion regulation, and assertiveness, and applied cognitive coping, and discussions showed weaker intervention effects for stimulating subdomains of the interpersonal domain than interventions that did not include these components.

\section{Discussion}

It is important to understand the intervention components that contribute to intervention effectiveness, or ineffectiveness, in order to guide intervention selection and implementation. Schools strive to improve their students' wellbeing, but their time and resources to invest in interventions are limited. This meta-analysis aimed to identify the intervention components that contribute to the effectiveness of universal secondary school-based interventions aiming to stimulate students intra- and interpersonal domains. In line with previous meta-analyses examining universal school-based interventions, we found small positive effects on students' intra- and interpersonal domains (e.g., Dray et al. 2017; Durlak et al. 2011; Jiménez-Barbero et al. 2016). Overall, none of the discrete components were consistently related to stronger or weaker effects on both students' intra- and interpersonal domains across the subdomains. In other words, components that were related to stronger or weaker intervention effects typically were so for more specific domains, highlighting the importance of matching intervention to specific competencies or problems. In terms of the type of components that matters most, content components seemed more relevant for stimulating both the intrapersonal domain (e.g., internalizing behavior) and the interpersonal domain (e.g., bullying). Importantly, components related to stronger intervention effects were not necessarily frequently implemented 
in interventions (e.g., in 10-19\% of the interventions). Similarly, components related to weaker intervention effects were generally implemented frequently (e.g., in $40-53 \%$ of the interventions).

Content components teaching students self-awareness (i.e., insight building) and problem solving were related to stronger effects, whereas components teaching emotion regulation, assertiveness, and cognitive coping were related to weaker effects. These findings are in line with previous research that indicated teaching self-awareness and problem solving as potential effective components (e.g., Boustani et al. 2015). Teaching emotion regulation, assertiveness, and cognitive coping might be more relevant in different contexts than the secondary school context in which the interventions were implemented. For instance, emotion regulation might be more relevant when implemented in psychotherapy (e.g., Weisz et al. 2012) and teaching assertiveness might be more relevant for students at elementary schools (e.g., Onrust et al. 2016). Teaching cognitive coping was related to weaker effects on interpersonal competences in general. This finding was somewhat surprising, given that cognitive coping is considered an effective component in other interventions as Cognitive Behavioral Therapy (Yovel et al. 2014) with well-trained therapists (Kobak et al. 2017). One possible explanation may be that school-based interventions, are often implemented by teachers who only received a short training (e.g., Challen et al. 2014) and have no to little experience in teaching cognitive coping. Taken together, content components might be differentially related to intervention effects in different contexts.

In general, instructional components that reflect an active learning approach were related to stronger intervention effects (e.g., relaxation, practice). This does not mean that interventions should only use active learning approaches and exclude more passive learning approaches. Interventions that used discussion as method delivery, an active learning component, were related to weaker intervention effects on aggression, whereas interventions using a didactic information delivery as method, a passive learning approach, were related to stronger intervention effects. These findings are in line with the meta-analysis of De Mooij et al. (2020) that showed that psychoeducation was related to stronger effects of Social Skills Training interventions. Using didactic instruction might fit better in the school context than using discussion. In a didactic instruction approach, the emphasis is on knowledge transfer between the teacher and the students, whereas a discussion approach is more dependent on the students and the social skills and cohesiveness of the group. Teachers might be less equipped to prevent a discussion from sidetracking than to teach psychological constructs (Horne et al. 2007).

The results concerning structural components showed that longer and more extensive interventions (e.g., involving parents and the whole school) were more effective for targeting system level outcomes such as school climate. Longterm and extensive interventions might be more effective when the intervention aims to increase students' feelings of safety at school. By targeting multiple systems in which the students are involved (e.g., school, family) teachers and parents might become more sensitive for problems students encounter, such as bullying or problematic relations with peers (Ttofi and Farrington 2011) and a broad range of risk factors is addressed (Trip et al. 2015). For interventions targeting the individual level such as self-esteem, more extensive interventions were not related to stronger effects nor were less extensive interventions related to weaker effects. Based on these findings, less extensive interventions might be preferred to stimulate the intrapersonal domain due to the easier implementation (Bakermans-Kranenburg et al. 2003), while more extensive interventions may be better suited to stimulate the interpersonal domain.

Furthermore, our results showed that components related to stronger intervention effects were not necessarily commonly implemented. For instance, interventions that involved the whole school were related to stronger effects on internalizing problems, bullying and school climate. However, only $10 \%$ to $19 \%$ of the included interventions involved the whole school. In contrast, some components that were related to weaker effects are implemented more often. For example, teaching emotion regulation, included in $40 \%$ to $53 \%$ of the interventions, was related to weaker effect sizes on the intrapersonal domain in general, self-esteem, and bullying. Our frequency counts of components are in line with the frequency count by Boustani et al. (2015) of effective school-based interventions. These findings indicate that it is important to critically consider which components to include in an intervention and to not simply "do what previously has been done."

Several limitations merit attention. First, we tested associations between components and intervention effectiveness. Based on these associations, we cannot state whether specifically these components are (in)effective or whether other components confounded with that specific component accounted for the association. Moreover, the analyzed components were not implemented in isolation, but in the context of an intervention program consisting of multiple components. Interactions among components can affect their effectiveness. In addition, it remains unclear how the components were implemented, how much time was allotted to certain components, and what the quality of implementation of the component was. These aspects could also influence components' effectiveness. This meta-analysis should therefore be regarded as hypothesis generating; our results give future research indications which components are interesting to examine further. Future research should test causal individual and synergistic effects of components, and 
potential order effects of components. Second, the coding of components depended on the sufficiency of the intervention description in the included studies; if a component was not mentioned in the article, or other freely available information concerning the evaluated interventions, it was coded as not present. At the same time, components that are formally part of the intervention, and therefore reported and coded as such, may not necessarily be implemented. It might be that some components were thus coded as "present" while they were not actually implemented. Third, even though we included more than 500 effect sizes, some components (e.g., peer resistance, parental involvement) were less frequently implemented in interventions than other components (e.g., practice, discussion) resulting in better powered analyses for some components than for others. Last, our outcome categories, the two general domains as well as the specific competencies and problems, were relatively broadly defined. On the one hand, these broad outcome categories are a good representation of the broad range of problems that may be present in the heterogeneous student population which schools aim to address with these universal interventions. On the other hand, the outcome categories may be less sensitive to change and could mask associations between specific components and specific outcomes.

In conclusion, when designing and implementing universal school-based interventions, and especially when no rigorous evidence base for the intervention is available, it is important to consider the evidence base of its included components. Some components are often implemented in interventions without being actually related to stronger intervention effects. In fact, some commonly implemented components (e.g., emotion regulation, discussion) were related to weaker intervention effects in our meta-analysis. Vice versa, some components that were related to stronger intervention effects (e.g., involvement of the whole school or parents) were only rarely included in interventions. Thus, it is essential to examine the evidence base of components before including it in an intervention, and to not solely focus on which components have been included in previous interventions. Selecting an intervention for implementation is complex and stakeholders need to take numerous factors into account (e.g., training of providers, match with the context, required resources). We hope our findings can contribute to this process by informing stakeholders which components may be important to be included in an intervention when aiming to address certain competencies or problems; schools can look up which components are associated with stronger effects on outcomes relevant for them and take this evidence-base into consideration in their decision. This meta-analysis provides an empirical foundation for the evidence base of components related to stronger and weaker effects for universal school-based interventions addressing the intra- and interpersonal domain.
Funding This work was supported by a grant from The Netherlands Organization for Health Research and Development, Grant Number 531001106

\section{Compliance with Ethical Standards}

Conflict of interest The authors declare that they have no conflict of interest.

Ethical Approval This article does not contain any studies with human participants performed by any of the authors.

Open Access This article is licensed under a Creative Commons Attribution 4.0 International License, which permits use, sharing, adaptation, distribution and reproduction in any medium or format, as long as you give appropriate credit to the original author(s) and the source, provide a link to the Creative Commons licence, and indicate if changes were made. The images or other third party material in this article are included in the article's Creative Commons licence, unless indicated otherwise in a credit line to the material. If material is not included in the article's Creative Commons licence and your intended use is not permitted by statutory regulation or exceeds the permitted use, you will need to obtain permission directly from the copyright holder. To view a copy of this licence, visit http://creativecommons.org/licenses/by/4.0/.

\section{Appendix A-complete list of search terms}

\begin{tabular}{ll}
\hline Category & Term \\
\hline Program descriptors & School, schools, class, classroom, \\
classes, school-based, "school \\
based", group, group-based, \\
"group based", high-school, \\
"secondary school" \\
Intervention, preventive, preven- \\
tion, program* \\
Adolescent, adolescence, ado- \\
lescents, youth, teen, teenager, \\
teenagers \\
"Psychological well-being", \\
resilience, resiliency, "emotional \\
adjustment", "self-efficacy", \\
"social isolation", "social identi- \\
fication", psychosexual, commu- \\
nication, communicative, anger, \\
aggression, aggressive, "social \\
Program outcomes \\
support", "social safety", "psy- \\
chosocial well-being", "emotion \\
regulation", "self-regulation", \\
"self-control", "self-esteem", \\
"self-worth", "self-confidence", \\
"peer problems", "relational \\
aggression", "externalizing \\
behavior", "externalizing \\
behavior", "internalizing behav- \\
ior", "internalizing behavior", \\
violence*, "social competence", \\
"positive social behavior*”, \\
"emotional distress", "prosocial \\
behavior*"
\end{tabular}




\begin{tabular}{ll}
\hline Category & Term \\
\hline Restrictions & Substance, drug, drugs, alcohol, \\
& smoking, lifestyle, "weight \\
loss", diet, dietary, obesity, \\
obese, disorder*, disease, clini- \\
cal, patient, patients, HIV, aids, \\
illness, disability*, disabled, \\
suicide, suicidal, anorexia, eat- \\
ing, pregnancy*, nurse*, neural, \\
neuron, college, university, \\
"primary school", preschool \\
\hline
\end{tabular}

\section{Appendix B-Definitions of Components*}

Content components: specific skills adolescents learn to promote positive outcomes

Emotion regulation

Assertiveness

Self-efficacy

Self-control

Insight building

Cognitive coping

Relaxation

Social skills

Problem solving

Peer resistance
Strategies to help youth identify and appropriately express emotions (including aggression)

Exercises designed to promote the youth's ability to assert his or her needs appropriately with others

Techniques and training to enhance self-confidence and improve self-efficacy

Strategies to help youth interrupt undesired behavioral tendencies (e.g., impulses) and refrain from acting on them

Activities specifically designed to help a youth achieve greater self-understanding and adjust attitudes

Any techniques designed to alter interpretation of events or deal with stressful situations through examination of the youth's reported thoughts (e.g., cognitive restructuring)

Techniques or exercises designed to induce physiological calming

Training youth how to communicate more effectively with others and providing constructive information, training, and feedback to improve interpersonal verbal or non-verbal functioning

Training in the use of techniques, discussions, or activities designed to bring about solutions to social, emotional, or behavioral problems

Techniques or training to learn youth how to resist pressure from peers

Instructional components: techniques and methods of information delivery used by the intervention facilitator

Practice

Modeling

Discussion

Goal setting

(Self-)monitoring

Multimedia

Homework

Number of components

Parental involvement

Whole school involved

Individual part
Didactic instruction

Practicing of a desired behavior during session (e.g., role-play)

Demonstration to the youth of a desired behavior

Discussion of topics within a group

The explicit selection of a therapeutic goal for the purpose of working toward achieving that goal

The repeated measurement of a target index (by the youth)

The use of multimedia to bring or reinforce new knowledge or skills

Written, verbal, or behavioral assignments to complete between sessions

The formal (usually didactic) review of information (e.g., psychoeducation)

Structural components: describe the structure of the intervention that might impact results

Parents are directly or indirectly involved during the intervention

The school staff is directly or indirectly involved during the intervention

The intervention includes additional individual guidance or explicit individual progress through the intervention (e.g., expressive writing, internetbased intervention)

Number of sessions of the intervention

Number of components implemented in the intervention

* Definitions are based on Boustani et al. (2015), Kaminski et al. (2008), Onrust et al. (2016), Peters et al. (2009), and Van der Put et al. (2018)

\section{Appendix C-Reliability Scores of Individual Codes}

\begin{tabular}{lll}
\hline Descriptive variables & Type of reliability & Reliability \\
\hline Year of publication & ICC & 1.00 \\
Country & Kappa & 0.86 \\
Mean age & ICC & 1.00 \\
Proportion boys & ICC & 0.99 \\
Ethnic composition & Kappa & 0.63
\end{tabular}




\begin{tabular}{|c|c|c|}
\hline Descriptive variables & Type of reliability & Reliability \\
\hline Randomization & Kappa & 0.80 \\
\hline Drop-out percentage & ICC & 1.00 \\
\hline Type of comparison group & Kappa & 0.87 \\
\hline Facilitator teacher & Kappa & 1.00 \\
\hline Facilitator professional & Kappa & 0.85 \\
\hline Facilitator peer & Kappa & 1.00 \\
\hline Timespan intervention & ICC & 0.99 \\
\hline Components & Type of reliability & Reliability \\
\hline \multicolumn{3}{|l|}{ Content components } \\
\hline Emotion regulation & Kappa & 0.87 \\
\hline Assertiveness & Kappa & 0.67 \\
\hline Self-efficacy & Kappa & 0.77 \\
\hline Self-control & Kappa & 0.87 \\
\hline Insight building & Kappa & 0.52 \\
\hline Cognitive coping & Kappa & 0.60 \\
\hline Relaxation & Kappa & 0.78 \\
\hline Social skills & Kappa & 0.80 \\
\hline Problem solving & Kappa & 0.87 \\
\hline Peer resistance & Kappa & 0.78 \\
\hline \multicolumn{3}{|l|}{ Instructional components } \\
\hline Practice & Kappa & 0.66 \\
\hline Modeling & Kappa & 0.66 \\
\hline Discussion & Kappa & 0.92 \\
\hline Goal setting & Kappa & 1.00 \\
\hline Self-monitoring & Kappa & 0.87 \\
\hline Multimedia & Kappa & 0.92 \\
\hline Homework & Kappa & 0.90 \\
\hline Didactic instruction & Kappa & 0.62 \\
\hline \multicolumn{3}{|l|}{ Structural components } \\
\hline Parental involvement & Kappa & 1.00 \\
\hline Whole school involved & Kappa & 0.64 \\
\hline Individual part & Kappa & 0.79 \\
\hline Number of sessions & ICC & 0.88 \\
\hline
\end{tabular}

\begin{tabular}{|c|c|c|c|c|c|}
\hline References & Name of intervention & Aim & Target & $\begin{array}{l}\text { Category } \\
\text { outcomes }\end{array}$ & Grades \\
\hline $\begin{array}{l}\text { Ando et al. } \\
\text { (2007) }\end{array}$ & $\begin{array}{l}\text { Adaptation of Going } \\
\text { Places Program }\end{array}$ & $\begin{array}{r}\text { Aggressive } \\
\text { behavior }\end{array}$ & Inter & $\begin{array}{l}\text { Self- } \\
\text { regulation, } \\
\text { aggression, } \\
\text { social com- } \\
\text { petence, } \\
\text { school } \\
\text { climate }\end{array}$ & 7 \\
\hline $\begin{array}{l}\text { Avery-leaf et al. } \\
\text { (1997) }\end{array}$ & $\begin{array}{l}\text { 1. Dating violence pre- } \\
\text { vention program }\end{array}$ & $\begin{array}{l}\text { Dating vio- } \\
\text { lence }\end{array}$ & Inter & Sexual health & 11,12 \\
\hline $\begin{array}{l}\text { Baker et al. } \\
\text { (2014) }\end{array}$ & Respect & $\begin{array}{l}\text { Sexual vio- } \\
\text { lence }\end{array}$ & Inter & Sexual health & $19-12$ \\
\hline $\begin{array}{l}\text { Barkoukis et al. } \\
\text { (2016) }\end{array}$ & $\begin{array}{l}\text { Intervention against } \\
\text { Cyberbullying }\end{array}$ & Cyberbullying & Inter & $\begin{array}{l}\text { Social com- } \\
\text { petence, } \\
\text { bullying }\end{array}$ & $7-11$ \\
\hline $\begin{array}{l}\text { Bonell et al. } \\
\quad(2018)\end{array}$ & $\begin{array}{l}\text { Learning Together } \\
\text { intervention }\end{array}$ & $\begin{array}{l}\text { Bullying, } \\
\text { aggression, } \\
\text { and wellbe- } \\
\text { ing }\end{array}$ & Inter & $\begin{array}{l}\text { Wellbeing, } \\
\text { aggression, } \\
\text { bullying }\end{array}$ & 7 \\
\hline $\begin{array}{l}\text { Bosworth et al. } \\
\text { (2000) }\end{array}$ & $\begin{array}{l}\text { SMART Talk (based } \\
\text { on BARN system) }\end{array}$ & $\begin{array}{l}\text { Problem solv- } \\
\text { ing without } \\
\text { violence }\end{array}$ & Inter & $\begin{array}{l}\text { Self-esteem, } \\
\text { aggression, } \\
\text { social com- } \\
\text { petence }\end{array}$ & $\begin{array}{l}6-8 \\
-\end{array}$ \\
\hline $\begin{array}{l}\text { Boulton and } \\
\text { Flemington } \\
(1996)\end{array}$ & $\begin{array}{l}\text { Sticks and stones } \\
\text { video }\end{array}$ & Bullying & Inter & Bullying & $6-9$ \\
\hline $\begin{array}{l}\text { Bradley et al. } \\
\text { (2010) }\end{array}$ & TestEdge & $\begin{array}{l}\text { Stress, anxiety, } \\
\text { wellbeing, } \\
\text { and relation- } \\
\text { ships }\end{array}$ & $\begin{array}{l}\text { Intra } \\
\text { and } \\
\text { inter }\end{array}$ & $\begin{array}{l}\text { Self-regula- } \\
\text { tion, inter- } \\
\text { nalizing, } \\
\text { wellbeing, } \\
\text { social com- } \\
\text { petence, } \\
\text { school } \\
\text { climate }\end{array}$ & 10 \\
\hline $\begin{array}{l}\text { Bull et al. } \\
\text { (2009) }\end{array}$ & The fairplayer.manual & $\begin{array}{l}\text { Bullying and } \\
\text { relational } \\
\text { aggression }\end{array}$ & Inter & Bullying & $9-11$ \\
\hline $\begin{array}{l}\text { Burckhardt } \\
\text { et al. (2016) }\end{array}$ & Strong Minds & $\begin{array}{l}\text { Subjective } \\
\text { wellbeing }\end{array}$ & Intra & Wellbeing & 9,10 \\
\hline $\begin{array}{l}\text { Burckhardt } \\
\text { et al. (2018) }\end{array}$ & $\begin{array}{l}\text { Dialectical behavior } \\
\text { therapy skills group }\end{array}$ & $\begin{array}{l}\text { Mental health } \\
\text { symptoms }\end{array}$ & Intra & $\begin{array}{l}\text { Self-regula- } \\
\text { tion, inter- } \\
\text { nalizing, } \\
\text { aggression }\end{array}$ & 10 \\
\hline $\begin{array}{l}\text { Burckhardt } \\
\text { et al. (2017) }\end{array}$ & $\begin{array}{l}\text { Acceptance and Com- } \\
\text { mitment Therapy } \\
(\mathrm{ACT})\end{array}$ & Wellbeing & Intra & $\begin{array}{l}\text { Internalizing, } \\
\text { wellbeing }\end{array}$ & 10 \\
\hline $\begin{array}{l}\text { Calear et al. } \\
\text { (2009) }\end{array}$ & MoodGym & $\begin{array}{l}\text { Anxiety and } \\
\text { depression }\end{array}$ & Intra & Internalizing & $8-10$ \\
\hline $\begin{array}{l}\text { Caplan et al. } \\
\text { (1992) }\end{array}$ & $\begin{array}{l}\text { The Positive Youth } \\
\text { Development } \\
\text { Program }\end{array}$ & $\begin{array}{l}\text { Personal and } \\
\text { social com- } \\
\text { petence }\end{array}$ & $\begin{array}{l}\text { Intra } \\
\text { and } \\
\text { inter }\end{array}$ & $\begin{array}{l}\text { Self-esteem, } \\
\text { self- } \\
\text { regulation, } \\
\text { wellbeing, } \\
\text { social com- } \\
\text { petence }\end{array}$ & $\begin{array}{l}6,7 \\
- \\
-\end{array}$ \\
\hline $\begin{array}{l}\text { Caprara et al. } \\
\text { (2014) }\end{array}$ & CEPIDEA & $\begin{array}{l}\text { Prosocial } \\
\text { behavior }\end{array}$ & Inter & $\begin{array}{l}\text { Self-esteem, } \\
\text { aggression, } \\
\text { social com- } \\
\text { petence }\end{array}$ & , \\
\hline $\begin{array}{l}\text { Carraro et al. } \\
\text { (2014) }\end{array}$ & Play fighting & $\begin{array}{r}\text { Aggressive } \\
\text { behavior }\end{array}$ & Inter & Aggression & 8 \\
\hline $\begin{array}{l}\text { Castillo-Gualda } \\
\text { et al. (2017) }\end{array}$ & $\begin{array}{l}\text { INTEMO (Long ver- } \\
\text { sion, } 3 \text { years) }\end{array}$ & Aggression & Inter & $\begin{array}{l}\text { Wellbeing, } \\
\text { aggression }\end{array}$ & 7 \\
\hline
\end{tabular}

\section{Appendix D-Descriptives of Included Publications}

\begin{tabular}{|c|c|c|c|c|c|}
\hline References & Name of intervention & Aim & Target & $\begin{array}{l}\text { Category } \\
\text { outcomes }\end{array}$ & Grades \\
\hline $\begin{array}{l}\text { Adler-Beader } \\
\text { et al. (2007) }\end{array}$ & $\begin{array}{l}\text { LoveU2: increasing } \\
\text { your relationship } \\
\text { smarts (RS adapted) }\end{array}$ & $\begin{array}{l}\text { Healthy roman } \\
\text { tic relation- } \\
\text { ships }\end{array}$ & -Inter & $\begin{array}{l}\text { Sexual } \\
\text { health, } \\
\text { social com- } \\
\text { petence }\end{array}$ & $9-12$ \\
\hline $\begin{array}{l}\text { Allara et al. } \\
\text { (2018) }\end{array}$ & $\begin{array}{l}\text { Diario della salute } \\
\text { (my health diary) }\end{array}$ & $\begin{array}{l}\text { Wellbeing and } \\
\text { health }\end{array}$ & Intra & $\begin{array}{l}\text { Wellbeing, } \\
\text { aggression, } \\
\text { school } \\
\text { climate }\end{array}$ & 7 \\
\hline
\end{tabular}




\begin{tabular}{|c|c|c|c|c|c|}
\hline References & Name of intervention & Aim & Target & $\begin{array}{l}\text { Category } \\
\text { outcomes }\end{array}$ & Grades \\
\hline $\begin{array}{l}\text { Challen et al. } \\
\text { (2014) }\end{array}$ & $\begin{array}{l}\text { UK Resilience } \\
\text { Program }\end{array}$ & Resilience & Intra & \multicolumn{2}{|c|}{$\begin{array}{l}\text { Internalizing, } 6 \\
\text { social com- } \\
\text { petence }\end{array}$} \\
\hline $\begin{array}{l}\text { Chang et al. } \\
\text { (2013) }\end{array}$ & $\begin{array}{l}\text { Laughing Qigong } \\
\text { Program }\end{array}$ & Stress & Intra & $\begin{array}{c}\text { Self-esteem, } \\
\text { wellbeing }\end{array}$ & 7 \\
\hline $\begin{array}{l}\text { Cheung and Lee } \\
\text { (2010) }\end{array}$ & eCharacter education & $\begin{array}{l}\text { Social compe- } \\
\text { tence }\end{array}$ & Inter & $\begin{array}{l}\text { Social com- } \\
\text { petence }\end{array}$ & 8,9 \\
\hline $\begin{array}{l}\text { Coelho et al. } \\
\text { (2015) }\end{array}$ & Positive Attitudes & $\begin{array}{l}\text { Social- } \\
\text { emotional } \\
\text { competence }\end{array}$ & $\begin{array}{l}\text { Intra } \\
\text { and } \\
\text { inter }\end{array}$ & $\begin{array}{l}\text { Self-esteem, } \\
\text { self- } \\
\text { regulation, } \\
\text { internaliz- } \\
\text { ing, social } \\
\text { compe- } \\
\text { tence }\end{array}$ & $7-9$ \\
\hline $\begin{array}{l}\text { Coker et al. } \\
\text { (2017) }\end{array}$ & $\begin{array}{l}\text { Green Dot violence } \\
\text { prevention program }\end{array}$ & $\begin{array}{l}\text { Sexual } \\
\text { violence and } \\
\text { interpersonal } \\
\text { violence }\end{array}$ & Inter & Aggression & $9-12$ \\
\hline $\begin{array}{l}\text { Connolly et al. } \\
\text { (2015) }\end{array}$ & $\begin{array}{l}\text { Respect in Schools } \\
\text { Everywhere (RISE) }\end{array}$ & $\begin{array}{l}\text { Bullying, } \\
\text { sexual } \\
\text { harassment, } \\
\text { and date } \\
\text { aggression }\end{array}$ & Inter & \multicolumn{2}{|c|}{$\begin{array}{l}\text { Internalizing, } 7,8 \\
\text { sexual } \\
\text { health, } \\
\text { bullying, } \\
\text { school } \\
\text { climate }\end{array}$} \\
\hline $\begin{array}{l}\text { Constantine } \\
\text { et al. (2015) }\end{array}$ & $\begin{array}{l}\text { Sexuality Education } \\
\text { Initiative }\end{array}$ & Sexual health & Inter & $\begin{array}{r}\text { Self-esteem, } \\
\text { aggression }\end{array}$ & 9 \\
\hline $\begin{array}{l}\text { Cross et al. } \\
\text { (2016) }\end{array}$ & Cyber Friendly Schoo & lCyberbullying & Inter & Bullying & 8,9 \\
\hline $\begin{array}{l}\text { Daly et al. } \\
\text { (2015) }\end{array}$ & Yoga & $\begin{array}{l}\text { Emotion regu- } \\
\text { lation }\end{array}$ & Intra & $\begin{array}{l}\text { Self-regula- } \\
\text { tion }\end{array}$ & NR \\
\hline $\begin{array}{l}\text { De Graaf et al. } \\
\text { (2016) }\end{array}$ & Rock and Water & $\begin{array}{l}\text { Sexual aggres- } \\
\text { sive behavior } \\
\text { and cogni- } \\
\text { tions }\end{array}$ & Inter & $\begin{array}{l}\text { Self-esteem, } \\
\text { self-regula- } \\
\text { tion, sexual } \\
\text { health }\end{array}$ & $\begin{array}{l}9,10 \\
- \\
1\end{array}$ \\
\hline $\begin{array}{l}\text { De Villiers and } \\
\text { Van den Berg } \\
\text { (2012) }\end{array}$ & Resilience program & Resilience & Intra & $\begin{array}{l}\text { Resilience, } \\
\text { self- } \\
\text { esteem, } \\
\text { self-regula- } \\
\text { tion, social } \\
\text { compe- } \\
\text { tence }\end{array}$ & 6 \\
\hline Domino (2013) & Take the lead & Social skills & Inter & Bullying & 7 \\
\hline $\begin{array}{l}\text { DuRant et al. } \\
\text { (1996) }\end{array}$ & $\begin{array}{l}\text { Violence prevention } \\
\text { curriculum for } \\
\text { adolescents }\end{array}$ & Violence use & Inter & Aggression & $6-8$ \\
\hline $\begin{array}{l}\text { DuRant et al. } \\
\text { (1996) }\end{array}$ & $\begin{array}{l}\text { Conflict resolution: } \\
\text { A curriculum for } \\
\text { youth providers }\end{array}$ & Violence use & Inter & Aggression & $6-8$ \\
\hline $\begin{array}{l}\text { Espelage et al. } \\
\text { (2013) }\end{array}$ & $\begin{array}{l}\text { Second Step: Student } \\
\text { Success Through } \\
\text { Prevention }\end{array}$ & Violence & Inter & $\begin{array}{l}\text { Aggression, } \\
\text { sexual } \\
\text { health, } \\
\text { bullying }\end{array}$ & 6 \\
\hline $\begin{array}{l}\text { Felver et al. } \\
\text { (2018) }\end{array}$ & $\begin{array}{l}\text { Learning to } \\
\text { BREATHE }\end{array}$ & $\begin{array}{l}\text { Wellbeing and } \\
\text { learning }\end{array}$ & Intra & Resilience & $9-12$ \\
\hline $\begin{array}{l}\text { Foshee et al. } \\
\quad(2005)\end{array}$ & Safe Dates & $\begin{array}{l}\text { Dating vio- } \\
\text { lence }\end{array}$ & Inter & Aggression & 8,9 \\
\hline
\end{tabular}

\begin{tabular}{|c|c|c|c|c|c|}
\hline References & Name of intervention & Aim & Target & $\begin{array}{l}\text { Category } \\
\text { outcomes }\end{array}$ & Grades \\
\hline $\begin{array}{l}\text { Frank et al. } \\
\text { (2016) }\end{array}$ & $\begin{array}{l}\text { Transformative life } \\
\text { skills }\end{array}$ & $\begin{array}{l}\text { Stress and } \\
\text { social- } \\
\text { emotional } \\
\text { health }\end{array}$ & Intra & $\begin{array}{l}\text { Self- } \\
\text { regulation, } \\
\text { wellbeing, } \\
\text { aggression, } \\
\text { school } \\
\text { climate }\end{array}$ & 6,9 \\
\hline $\begin{array}{l}\text { Freire et al. } \\
\quad(2018)\end{array}$ & Challenge: To $\mathrm{Be}+$ & $\begin{array}{l}\text { Positive devel- } \\
\text { opment }\end{array}$ & $\begin{array}{l}\text { Intra } \\
\text { and } \\
\text { inter }\end{array}$ & $\begin{array}{l}\text { Self-esteem, } \\
\text { wellbeing }\end{array}$ & 9 \\
\hline $\begin{array}{l}\text { Garaigordobil } \\
\text { (2004) }\end{array}$ & $\begin{array}{l}\text { Psychological } \\
\text { intervention carried } \\
\text { out with groups of } \\
\text { adolescents }\end{array}$ & $\begin{array}{l}\text { Emotional } \\
\text { development }\end{array}$ & Intra & $\begin{array}{l}\text { Self-esteem, } \\
\text { self- } \\
\text { regulation, } \\
\text { internaliz- } \\
\text { ing, social } \\
\text { compe- } \\
\text { tence }\end{array}$ & NR \\
\hline $\begin{array}{l}\text { Garaigordobil } \\
\text { and Martinez- } \\
\text { Valderrey } \\
\text { (2015a), } \\
\text { Garaigordobil } \\
\text { and Martinez- } \\
\text { Valderrey } \\
\text { (2015b) and } \\
\text { Garaigordobil } \\
\text { (2014) }\end{array}$ & Cyberprogram 2.0 & $\begin{array}{l}\text { Interpersonal } \\
\text { conflicts and } \\
\text { self-esteem }\end{array}$ & $\begin{array}{l}\text { Intra } \\
\text { and } \\
\text { inter }\end{array}$ & $\begin{array}{l}\text { Self-esteem, } \\
\text { internaliz- } \\
\text { ing, social } \\
\text { compe- } \\
\text { tence, } \\
\text { bullying, } \\
\text { aggression }\end{array}$ & 9,10 \\
\hline $\begin{array}{l}\text { Gardner et al. } \\
\text { (2004) }\end{array}$ & $\begin{array}{l}\text { Connections: } \\
\text { Relationships and } \\
\text { Marriage }\end{array}$ & $\begin{array}{l}\text { Healthy roman- } \\
\text { tic relations }\end{array}$ & -Inter & $\begin{array}{l}\text { Aggression, } \\
\text { sexual } \\
\text { health }\end{array}$ & 11,12 \\
\hline $\begin{array}{l}\text { Ghahremani } \\
\text { et al. (2013) }\end{array}$ & $\begin{array}{l}\text { Youth empowerment } \\
\text { SEminar (YES) }\end{array}$ & $\begin{array}{l}\text { Emotional } \\
\text { wellbeing }\end{array}$ & Intra & $\begin{array}{l}\text { Self-regula- } \\
\text { tion }\end{array}$ & $7-12$ \\
\hline $\begin{array}{l}\text { Gianotta et al. } \\
\text { (2009) }\end{array}$ & Expressive writing & $\begin{array}{l}\text { Negative out- } \\
\text { comes asso- } \\
\text { ciated with } \\
\text { peer-related } \\
\text { problems }\end{array}$ & Inter & $\begin{array}{l}\text { Self- } \\
\text { regulation, } \\
\text { bullying }\end{array}$ & 7 \\
\hline $\begin{array}{l}\text { Gigantesco } \\
\text { et al. (2015) }\end{array}$ & $\begin{array}{l}\text { Definizione di obiet- } \\
\text { tivi e soluzione di } \\
\text { problemi (estab- } \\
\text { lishing goals and } \\
\text { problems solving) }\end{array}$ & $\begin{array}{l}\text { Self-efficacy, } \\
\text { psychologi- } \\
\text { cal wellbe- } \\
\text { ing, and life } \\
\text { satisfaction }\end{array}$ & Intra & $\begin{array}{l}\text { Self- } \\
\text { regulation, } \\
\text { wellbeing }\end{array}$ & $9-11$ \\
\hline $\begin{array}{l}\text { Gollwitzer et al. } \\
\text { (2007) }\end{array}$ & $\begin{array}{l}\text { Vienna Social Com- } \\
\text { petence Training } \\
\text { (ViSC) }\end{array}$ & $\begin{array}{l}\text { Class com- } \\
\text { mitment, } \\
\text { responsibil- } \\
\text { ity, and } \\
\text { nonaggres- } \\
\text { sive behavior } \\
\text { in conflict }\end{array}$ & Inter & Aggression & $6-8$ \\
\hline $\begin{array}{l}\text { Gouda et al. } \\
\text { (2016) }\end{array}$ & $\begin{array}{l}\text { Mindfulness-based } \\
\text { stress education } \\
\text { group program }\end{array}$ & $\begin{array}{l}\text { Performance } \\
\text { pressure }\end{array}$ & Intra & $\begin{array}{l}\text { Self-esteem, } \\
\text { self-regula- } \\
\text { tion, inter- } \\
\text { nalizing, } \\
\text { wellbeing, } \\
\text { social com- } \\
\text { petence }\end{array}$ & - \\
\hline $\begin{array}{l}\text { Haines and Ell- } \\
\text { mann (1994) }\end{array}$ & $\begin{array}{l}\text { Stress inoculation } \\
\text { training }\end{array}$ & $\begin{array}{l}\text { Negative } \\
\text { arousal in } \\
\text { response to } \\
\text { stress }\end{array}$ & Intra & $\begin{array}{c}\text { Internalizing, } \\
\text { wellbeing, } \\
\text { aggression }\end{array}$ & ,9-12 \\
\hline $\begin{array}{l}\text { Hains and } \\
\text { Szyjakowski } \\
(1990)\end{array}$ & $\begin{array}{l}\text { Cognitive intervention } \\
\text { training program }\end{array}$ & $\begin{array}{l}\text { nCope with } \\
\text { stress and } \\
\text { negative } \\
\text { arousal }\end{array}$ & Intra & $\begin{array}{l}\text { Self-esteem, } \\
\text { internal- } \\
\text { izing, } \\
\text { aggression }\end{array}$ & 11,12 \\
\hline
\end{tabular}




\begin{tabular}{|c|c|c|c|c|c|c|c|c|c|c|c|}
\hline References & Name of intervention & Aim & Target & $\begin{array}{l}\text { Category } \\
\text { outcomes }\end{array}$ & Grades & References & Name of intervention & Aim & Target & $\begin{array}{l}\text { Category } \\
\text { outcomes }\end{array}$ & Grades \\
\hline \multirow[t]{2}{*}{ Hains (1994) } & \multirow[t]{2}{*}{$\begin{array}{l}\text { Stress inoculation } \\
\text { training }\end{array}$} & \multirow{2}{*}{$\begin{array}{l}\text { Negative } \\
\text { arousal in } \\
\text { response to } \\
\text { stress }\end{array}$} & \multirow[t]{2}{*}{ Intra } & \multirow{2}{*}{$\begin{array}{l}\text { Self-esteem, } \\
\text { internal- } \\
\text { izing, } \\
\text { wellbeing, } \\
\text { aggression }\end{array}$} & \multirow[t]{2}{*}{ NR } & $\begin{array}{l}\text { Noggle et al. } \\
\text { (2012) }\end{array}$ & Kripalu yoga & \multicolumn{2}{|c|}{$\begin{array}{l}\text { Overall wellbe-Intra } \\
\text { ing }\end{array}$} & $\begin{array}{l}\text { Resilience, } \\
\text { wellbeing, } \\
\text { aggression }\end{array}$ & 11,12 \\
\hline & & & & & & $\begin{array}{l}\text { Orpinas et al. } \\
\text { (1995) }\end{array}$ & $\begin{array}{l}\text { Second Step: A } \\
\text { violence prevention }\end{array}$ & Violence & Inter & $\begin{array}{l}\text { Self-esteem, } \\
\text { aggression }\end{array}$ & 6 \\
\hline \multirow{2}{*}{$\begin{array}{l}\text { Haynes and } \\
\text { Avery (1979) }\end{array}$} & \multirow{2}{*}{$\begin{array}{l}\text { Communication skills } \\
\text { training program }\end{array}$} & \multirow{2}{*}{$\begin{array}{r}\text { Self-disclosure } \\
\text { and empathy }\end{array}$} & \multirow{2}{*}{ Intra } & \multirow{2}{*}{\multicolumn{2}{|c|}{$\begin{array}{l}\text { Self-esteem, } 11 \\
\text { social com- } \\
\text { petence }\end{array}$}} & & curriculum & & & & \\
\hline & & & & & & $\begin{array}{l}\text { Ortega-Barón } \\
\text { et al. (2019) }\end{array}$ & Prev@cib & $\begin{array}{l}\text { Bullying and I } \\
\text { cyberbul- }\end{array}$ & Inter & Bullying & $7-10$ \\
\hline \multirow{2}{*}{$\begin{array}{l}\text { Horn et al. } \\
\quad(2010)\end{array}$} & \multirow{2}{*}{$\begin{array}{l}\text { JES! Jugendpräven- } \\
\text { tionsprogramm } \\
\text { mit Expressivem } \\
\text { Schreiben }\end{array}$} & \multirow{2}{*}{$\begin{array}{l}\text { Emotion regu- } \\
\text { lation }\end{array}$} & \multirow{2}{*}{ Intra } & \multirow[t]{2}{*}{ Wellbeing } & \multirow[t]{2}{*}{8} & & & & & & \\
\hline & & & & & & $\begin{array}{l}\text { Pacifici et al. } \\
\text { (2001) }\end{array}$ & $\begin{array}{c}\text { Dating and Sexual } \\
\text { Responsibility }\end{array}$ & $\begin{array}{l}\text { Dating vio- } \\
\text { lence }\end{array}$ & Inter & Sexual health & 10 \\
\hline \multirow[t]{2}{*}{$\begin{array}{l}\text { Huppert and } \\
\text { Johnson } \\
(2010)\end{array}$} & \multirow[t]{2}{*}{$\begin{array}{l}\text { Mindfulness-based } \\
\text { stress reduction }\end{array}$} & \multirow{2}{*}{$\begin{array}{l}\text { Mindfulness, } \\
\text { resilience, } \\
\text { and psy- } \\
\text { chological } \\
\text { wellbeing }\end{array}$} & \multirow[t]{2}{*}{ Intra } & \multirow[t]{2}{*}{$\begin{array}{r}\text { Resilience, } \\
\text { wellbeing }\end{array}$} & \multirow[t]{2}{*}{8} & $\begin{array}{l}\text { Proctor et al. } \\
\quad(2011)\end{array}$ & Strengths Gym & $\begin{array}{l}\text { Build strengths I } \\
\text { and learn } \\
\text { new } \\
\text { strengths }\end{array}$ & Intra & $\begin{array}{l}\text { Wellbeing, } \\
\text { self-esteem }\end{array}$ & 7,8 \\
\hline & & & & & & $\begin{array}{l}\text { Richardson } \\
\text { et al. (2009) }\end{array}$ & BodyThink & Self-esteem & Intra & $\begin{array}{l}\text { Self-esteem, } \\
\text { bullying }\end{array}$ & 7 \\
\hline $\begin{array}{l}\text { Ingram et al. } \\
\text { (2019) }\end{array}$ & $\begin{array}{l}\text { Stand up: Virtual } \\
\text { reality to activate } \\
\text { bystanders against } \\
\text { bullying }\end{array}$ & Bullying & Inter & $\begin{array}{l}\text { Aggression, } \\
\text { social com- } \\
\text { petence, } \\
\text { bullying, } \\
\text { school } \\
\text { climate }\end{array}$ & 7,8 & $\begin{array}{l}\text { Ruini et al. } \\
\text { (2006) }\end{array}$ & $\begin{array}{l}\text { Cognitive Behavioral } \\
\text { Therapy }\end{array}$ & $\begin{array}{l}\text { Mood disorder I } \\
\text { and psycho- } \\
\text { biological } \\
\text { distress }\end{array}$ & Intra & \multirow{2}{*}{$\begin{array}{l}\text { Resilience, } \\
\text { self- } \\
\text { esteem, } \\
\text { self-regula- } \\
\text { tion, inter- } \\
\text { nalizing, } \\
\text { wellbeing, } \\
\text { aggression, } \\
\text { social com- } \\
\text { petence }\end{array}$} & \multirow[t]{2}{*}{ NR } \\
\hline $\begin{array}{l}\text { Jaycox et al. } \\
\text { (2006) }\end{array}$ & $\begin{array}{l}\text { Ending violence: } \\
\text { A curriculum for } \\
\text { educating teens on } \\
\text { domestic violence } \\
\text { and the las }\end{array}$ & $\begin{array}{l}\text { Intimate part- } \\
\text { ner violence }\end{array}$ & Inter & Sexual health & & & & & & & \\
\hline $\begin{array}{l}\text { Jiménez- } \\
\text { Barbero et al. } \\
\text { (2016) }\end{array}$ & Count on me & $\begin{array}{l}\text { Bullying and } \\
\text { violence }\end{array}$ & Inter & Aggression & 7,8 & $\begin{array}{l}\text { Ruini et al. } \\
\text { (2006) }\end{array}$ & $\begin{array}{l}\text { Well-being therapy } \\
\text { (WBT) }\end{array}$ & $\begin{array}{l}\text { Psychological I } \\
\text { wellbeing }\end{array}$ & Intra & $\begin{array}{l}\text { Resilience, } \\
\text { self- } \\
\text { esteem, }\end{array}$ & NR \\
\hline $\begin{array}{l}\text { Kasler et al. } \\
\text { (2013) }\end{array}$ & $\begin{array}{l}\text { Meaning of Life pro- } \\
\text { gram (Israeli adap- } \\
\text { tation of the Laws } \\
\text { of Life program) }\end{array}$ & Meaning in life & Intra & $\begin{array}{l}\text { Self-esteem, } \\
\text { wellbeing, } \\
\text { school } \\
\text { climate }\end{array}$ & 10,11 & & & & & $\begin{array}{l}\text { self-regula- } \\
\text { tion, inter- } \\
\text { nalizing, } \\
\text { wellbeing, } \\
\text { aggression, }\end{array}$ & \\
\hline $\begin{array}{l}\text { Kaveh et al. } \\
\text { (2014) }\end{array}$ & $\begin{array}{l}\text { Peer led training } \\
\text { program }\end{array}$ & Self-esteem & Intra & Self-esteem & 7 & & & & & $\begin{array}{l}\text { social com- } \\
\text { petence }\end{array}$ & \\
\hline $\begin{array}{l}\text { Khanna and } \\
\text { Singh (2016) }\end{array}$ & $\begin{array}{l}\text { Nice Thinking } \\
\text { (adjusted to Indian } \\
\text { culture) }\end{array}$ & $\begin{array}{l}\text { Gratitude and } \\
\text { wellbeing }\end{array}$ & Intra & Wellbeing & 7 & $\begin{array}{l}\text { Ruini et al. } \\
\text { (2009) }\end{array}$ & $\begin{array}{l}\text { Well-being Therapy } \\
\text { (WBT) with added } \\
\text { cognitive-behavioral } \\
\text { packages }\end{array}$ & $\begin{array}{l}\text { Psychological I } \\
\text { wellbeing } \\
\text { and optimal } \\
\text { functioning }\end{array}$ & Intra & $\begin{array}{l}\text { Self-regula- } \\
\text { tion, inter- } \\
\text { nalizing, } \\
\text { wellbeing, }\end{array}$ & 9,10 \\
\hline $\begin{array}{l}\text { Kiselica et al. } \\
\text { (1994) }\end{array}$ & $\begin{array}{l}\text { Stress inoculation } \\
\text { training with asser- } \\
\text { tiveness training }\end{array}$ & $\begin{array}{l}\text { Anxiety and } \\
\text { stress }\end{array}$ & Intra & $\begin{array}{l}\text { Internalizing, } \\
\text { wellbeing }\end{array}$ & & & & & & $\begin{array}{l}\text { aggression, } \\
\text { social com- } \\
\text { petence }\end{array}$ & \\
\hline $\begin{array}{l}\text { Klingman and } \\
\text { Horchdof } \\
\text { (1993) }\end{array}$ & $\begin{array}{l}\text { Cognitive-behavioral } \\
\text { oriented distress- } \\
\text { coping training }\end{array}$ & Distress-coping & gIntra & $\begin{array}{l}\text { Wellbeing, } \\
\text { social com- } \\
\text { petence }\end{array}$ & 8 & $\begin{array}{l}\text { Ruiz-Aranda } \\
\text { et al. (2012) }\end{array}$ & INTEMO & $\begin{array}{l}\text { Aggressive } \\
\text { behaviors, } \\
\text { psychosocial } \\
\text { maladjust- }\end{array}$ & $\begin{array}{l}\text { Intra } \\
\text { and } \\
\text { inter }\end{array}$ & $\begin{array}{l}\text { Self-esteem, } \\
\text { internal- } \\
\text { izing, } \\
\text { wellbeing, }\end{array}$ & 7 \\
\hline $\begin{array}{l}\text { Kozina }(2018 a) \\
\text { and Kozina } \\
(2018 b)\end{array}$ & My FRIENDS & Anxiety & Intra & $\begin{array}{c}\text { Internalizing, } \\
\text { aggression }\end{array}$ & & & & $\begin{array}{l}\text { ment, and } \\
\text { mental health }\end{array}$ & & $\begin{array}{l}\text { social com- } \\
\text { petence }\end{array}$ & \\
\hline $\begin{array}{l}\text { Lamke et al. } \\
\text { (1988) }\end{array}$ & $\begin{array}{l}\text { Cognitive-behavior } \\
\text { modification } \\
\text { program }\end{array}$ & $\begin{array}{l}\text { Self-statements } \\
\text { and self- } \\
\text { esteem }\end{array}$ & Intra & Self-esteem & 9 & $\begin{array}{l}\text { Sánchez- } \\
\text { Jiménez et al. } \\
\text { (2018) }\end{array}$ & Dat-e Adolescence & $\begin{array}{l}\text { Dating vio- } \\
\text { lence }\end{array}$ & Inter & $\begin{array}{l}\text { Self-esteem, } \\
\text { aggression, } \\
\text { sexual } \\
\text { health }\end{array}$ & $7-10$ \\
\hline $\begin{array}{l}\text { Macgowan } \\
\text { (1997) }\end{array}$ & $\begin{array}{l}\text { Dating violence pre- } \\
\text { vention program }\end{array}$ & $\begin{array}{l}\text { Dating vio- } \\
\text { lence }\end{array}$ & Inter & Aggression & $6-8$ & Schramm and & Relationship Smarts & Healthy roman-I & -Inter & Sexual health & $8-12$ \\
\hline $\begin{array}{l}\text { Menesini et al. } \\
\text { (2003) }\end{array}$ & Peer support model & Bullying & Inter & Bullying & $6-8$ & $\begin{array}{l}\text { Gomez-Scott } \\
\text { (2012) }\end{array}$ & Plus & $\begin{array}{l}\text { tic relation- } \\
\text { ships }\end{array}$ & & & \\
\hline $\begin{array}{l}\text { Muck et al. } \\
\text { (2018) }\end{array}$ & $\begin{array}{l}\text { Scientist practitioner } \\
\text { program }\end{array}$ & $\begin{array}{l}\text { Sexual vio- } \\
\text { lence }\end{array}$ & Inter & Sexual health $\varepsilon$ & 18,9 & Schultz et al. & Facing History and & Perspective- I & Inter & Self-esteem, & 8 \\
\hline Nash (2007) & $\begin{array}{l}\text { Empower youth } \\
\text { program (and Usual } \\
\text { school services) }\end{array}$ & $\begin{array}{l}\text { Health, wellbe- } \\
1 \text { ing, and } \\
\text { optimism for } \\
\text { futures }\end{array}$ & - Intra & Internalizing & $6-8$ & & & $\begin{array}{l}\text { takıng, crit1- } \\
\text { cal thinking, } \\
\text { and more } \\
\text { decisions }\end{array}$ & & $\begin{array}{l}\text { aggression, } \\
\text { social com- } \\
\text { petence }\end{array}$ & \\
\hline
\end{tabular}




\begin{tabular}{|c|c|c|c|c|c|c|c|c|c|c|c|}
\hline References & Name of intervention & Aim & Target & $\begin{array}{l}\text { Category } \\
\text { outcomes }\end{array}$ & Grades & References & Name of intervention & Aim & Target & $\begin{array}{l}\text { Category } \\
\text { outcomes }\end{array}$ & Grades \\
\hline $\begin{array}{l}\text { Shek and Ma } \\
\text { (2011) }\end{array}$ & $\begin{array}{l}\text { Positive Adolescent } \\
\text { Training through } \\
\text { Holistic Social Pro- } \\
\text { grams (P.A.T.H.S.) }\end{array}$ & $\begin{array}{l}\text { Holistic youth } \\
\text { development }\end{array}$ & $\begin{array}{l}\text { Intra } \\
\text { and } \\
\text { inter }\end{array}$ & $\begin{array}{l}\text { Resilience, } \\
\text { self- } \\
\text { esteem, } \\
\text { self-regula- } \\
\text { tion, social } \\
\text { compe- }\end{array}$ & $\begin{array}{l}7 \\
- \\
-\end{array}$ & $\begin{array}{l}\text { Van der Meulen } \\
\text { et al. (2010) }\end{array}$ & $\begin{array}{l}\text { Adjusted version of } \\
\text { EQUIP program for } \\
\text { Educators }\end{array}$ & $\begin{array}{l}\text { Peer victimiza- } \\
\text { tion }\end{array}$ & - Inter & $\begin{array}{l}\text { Sexual } \\
\text { health, } \\
\text { bullying, } \\
\text { school } \\
\text { climate }\end{array}$ & 8,9 \\
\hline \multirow[t]{2}{*}{$\begin{array}{l}\text { Shinde et al. } \\
\text { (2018) }\end{array}$} & $\begin{array}{l}\text { Strengthening } \\
\text { evidence base on } \\
\text { school-based inter- } \\
\text { ventions for promot- }\end{array}$ & $\begin{array}{l}\text { School climate } \\
\text { and health- } \\
\text { promoting } \\
\text { behaviors }\end{array}$ & $\begin{array}{l}\text { Intra } \\
\text { and } \\
\text { inter }\end{array}$ & $\begin{array}{l}\text { Internalizing, } \\
\text { aggression, } \\
\text { bullying, } \\
\text { school }\end{array}$ & & $\begin{array}{l}\text { Van Schoiack- } \\
\text { Edstrom et al. } \\
\text { (2002) }\end{array}$ & $\begin{array}{l}\text { The Second Step, } \\
\text { Middle school/Jun- } \\
\text { ior High program }\end{array}$ & $\begin{array}{l}\text { Prosocial } \\
\text { skills and } \\
\text { impulsive- } \\
\text { aggressive } \\
\text { behavior }\end{array}$ & Inter & $\begin{array}{l}\text { Aggression, } \\
\text { social com- } \\
\text { petence }\end{array}$ & 6,7 \\
\hline & $\begin{array}{l}\text { ing adolescent } \\
\text { health (SEHER) }\end{array}$ & & & climate & & $\begin{array}{l}\text { Williams et al. } \\
\text { (2015) and }\end{array}$ & $\begin{array}{l}\text { Start strong: Build- } \\
\text { ing healthy teen }\end{array}$ & $\begin{array}{l}\text { Healthy } \\
\text { romantic }\end{array}$ & Inter & $\begin{array}{l}\text { Aggression, } \\
\text { bullying, }\end{array}$ & 7 \\
\hline $\begin{array}{l}\text { Shoshani and } \\
\text { Steinmetz } \\
\text { (2014) }\end{array}$ & $\begin{array}{l}\text { Maytiv School } \\
\text { Program }\end{array}$ & $\begin{array}{l}\text { Mental health } \\
\text { and empow- } \\
\text { erment }\end{array}$ & Intra & $\begin{array}{c}\text { Self-esteem, } \\
\text { wellbeing }\end{array}$ & $7-9$ & $\begin{array}{l}\text { Miller et al. } \\
\text { (2015) }\end{array}$ & relationships & $\begin{array}{l}\text { relationships } \\
\text { and dating } \\
\text { violence }\end{array}$ & & $\begin{array}{l}\text { sexual } \\
\text { health, } \\
\text { social com- }\end{array}$ & \\
\hline Sibinga et al. & Mindfulness-based & Psychological & Intra & Internalizing, & $, 7,8$ & & & & & & \\
\hline (2013) & $\begin{array}{l}\text { stress reduction } \\
\text { program }\end{array}$ & $\begin{array}{l}\text { symptoms } \\
\text { and coping }\end{array}$ & & aggression & & $\begin{array}{l}\text { Williford et al. } \\
\text { (2013) }\end{array}$ & $\begin{array}{l}\text { KiVa antibullying } \\
\text { program }\end{array}$ & $\begin{array}{l}\text { Cyberbullying } \\
\text { and victimi- } \\
\text { zation }\end{array}$ & Inter & Bullying & 8,9 \\
\hline $\begin{array}{l}\text { Simons-Morton } \\
\text { et al. (2005) }\end{array}$ & Going Places Program & $\begin{array}{l}\text { Social skills } \\
\text { and problem } \\
\text { behaviors }\end{array}$ & Inter & Aggression & 6 & $\begin{array}{l}\text { Wong et al. } \\
\text { (2011) }\end{array}$ & $\begin{array}{l}\text { Restorative Whole- } \\
\text { school Approach }\end{array}$ & Bullying & Inter & $\begin{array}{l}\text { Self-esteem, } \\
\text { social com- } \\
\text { petence, }\end{array}$ & $-7-9$ \\
\hline $\begin{array}{l}\text { Soliday et al. } \\
(2004)\end{array}$ & $\begin{array}{l}\text { Expressive writing } \\
\text { Intervention }\end{array}$ & $\begin{array}{l}\text { Positive func- } \\
\text { tioning and } \\
\text { stress }\end{array}$ & Intra & $\begin{array}{l}\text { Internalizing, } \\
\text { wellbeing }\end{array}$ & & & & & & $\begin{array}{l}\text { bullying, } \\
\text { school } \\
\text { climate }\end{array}$ & \\
\hline $\begin{array}{l}\text { Solomontos- } \\
\text { Kountouri } \\
\text { et al. (2016) }\end{array}$ & $\begin{array}{l}\text { ViSC social com- } \\
\text { petence program } \\
\text { (with added parental }\end{array}$ & $\begin{array}{l}\text { Victimization } \\
\text { and aggres- } \\
\text { sive behavior }\end{array}$ & Inter & $\begin{array}{l}\text { Aggression, } \\
\text { bullying }\end{array}$ & 7,8 & $\begin{array}{l}\text { Yom and Eun } \\
\text { (2005) }\end{array}$ & $\begin{array}{l}\text { Educational Program } \\
\text { for the Prevention of } \\
\text { Sexual Violence }\end{array}$ & $\begin{array}{l}\text { Sexual vio- } \\
\text { f lence }\end{array}$ & Inter & Sexual health & 16 \\
\hline
\end{tabular}

Intra intrapersonal domain, Inter interpersonal domain, NR not reported

\begin{tabular}{|c|c|c|c|c|c|}
\hline $\begin{array}{l}\text { Sorrentino et al. } \\
\text { (2018) }\end{array}$ & $\begin{array}{l}\text { Tabby Improved } \\
\text { Prevention and } \\
\text { Intervention Pro- } \\
\text { gram (TIPIP) }\end{array}$ & $\begin{array}{l}\text { Cyberbullying } \\
\text { and victimi- } \\
\text { zation }\end{array}$ & Inter & Bullying & NR \\
\hline $\begin{array}{l}\text { Stevens et al. } \\
\quad(2000)\end{array}$ & $\begin{array}{l}\text { Flemish anti-bullying } \\
\text { program }\end{array}$ & $\begin{array}{l}\text { Bullying and } \\
\text { victimization }\end{array}$ & Inter & $\begin{array}{l}\text { Social com- } \\
\text { petence, } \\
\text { bullying }\end{array}$ & NR \\
\hline $\begin{array}{l}\text { Thomaes et al. } \\
\text { (2009) }\end{array}$ & $\begin{array}{l}\text { Self-affirmation } \\
\text { intervention }\end{array}$ & $\begin{array}{l}\text { Narcissistic } \\
\text { aggression }\end{array}$ & Inter & $\begin{array}{l}\text { Self-esteem, } \\
\text { aggression }\end{array}$ & 7,8 \\
\hline $\begin{array}{l}\text { Thompkins } \\
\text { et al. (2014) }\end{array}$ & $\begin{array}{l}\text { Violence Prevention } \\
\text { Project }\end{array}$ & $\begin{array}{l}\text { Conflict resolu- } \\
\text { tion skills }\end{array}$ & -Inter & $\begin{array}{l}\text { Social com- } \\
\text { petence }\end{array}$ & 9,10 \\
\hline $\begin{array}{l}\text { Tomyn et al. } \\
\text { (2016) }\end{array}$ & $\begin{array}{l}\text { Think Health and } \\
\text { Wellbeing }\end{array}$ & $\begin{array}{l}\text { Thinking style, } \\
\text { self-esteem, } \\
\text { and resil- } \\
\text { ience }\end{array}$ & & $\begin{array}{l}\text { Resilience, } \\
\text { self- } \\
\text { esteem, } \\
\text { internal- } \\
\text { izing }\end{array}$ & 8 \\
\hline $\begin{array}{l}\text { Trip et al. } \\
\text { (2015) }\end{array}$ & $\begin{array}{l}\text { Rational Emotive } \\
\text { Behavioral Educa- } \\
\text { tion (REBE) }\end{array}$ & $\begin{array}{l}\text { Negative } \\
\text { dysfunctional } \\
\text { emotions and } \\
\text { alterna- } \\
\text { tive to low } \\
\text { frustration } \\
\text { tolerance }\end{array}$ & Intra & $\begin{array}{l}\text { Aggression, } \\
\text { bullying }\end{array}$ & 6 \\
\hline $\begin{array}{l}\text { Trip et al. } \\
\text { (2015) and } \\
\text { Yanagida } \\
\text { et al. (2019) }\end{array}$ & $\begin{array}{l}\text { Viennese Social Com- } \\
\text { petence (ViSC) }\end{array}$ & $\begin{array}{l}\text { - Bullying and } \\
\text { aggressive } \\
\text { behavior }\end{array}$ & Inter & $\begin{array}{l}\text { Aggression, } \\
\text { bullying }\end{array}$ & 6,7 \\
\hline $\begin{array}{l}\text { Tunariu et al. } \\
\text { (2017) }\end{array}$ & iNEAR & $\begin{array}{l}\text { Positive identi- } \\
\text { ties, charac- } \\
\text { ter strengths, } \\
\text { and resil- } \\
\text { ience }\end{array}$ & Intra & $\begin{array}{l}\text { Wellbeing, } \\
\text { social com- } \\
\text { petence }\end{array}$ & 6,7 \\
\hline
\end{tabular}

\section{Appendix E-Definitions of the General Domains and the Subdomains \\ Intrapersonal Domain}

The ability to manage one's own feelings, emotions, and attitudes about the self (Barber 2005). This domain concerns the subjective processing of behaviors, thoughts, and emotions pertained by the individual self (Dufner et al. 2019; Finkel and Vohs 2006). Evaluating and regulating one's own inner world and experiences can facilitate positive personal functioning (e.g., psychological wellbeing and resilience), whereas difficulties in this process can increase the chance of developing psychological problems (e.g., internalizing behavior; Dufner et al. 2019).

- Resilience the ability to bounce back from the variety of challenges that can arise in life (Campbell-Sills and Stein 2007).

- Self-esteem the extent to which individuals like themselves as a person in general or on specific domains (Wichstraum 1995). 
- Self-regulation the automatic or deliberate modulation of affect, behavior, and cognition (Karoly 1993).

- General wellbeing the presence of positive emotions and life satisfaction, and the absence of negative feelings (Robitail et al. 2007).

- Internalizing problems a broad range of mood and anxiety behaviors directed towards one's inner world putting an individual at risk of developing later mood and anxiety disorders (Petty et al. 2008).

\section{Interpersonal Domain}

The ability to build and maintain positive relationships with others, to understand social situations, roles and norms, and to respond appropriately (Pellegrino and Hilton 2012; Shek and Leung 2016). By planning one's own behavior and predicting the behavior of others one can act in a socially appealing way, such as building positive interpersonal relations, or in a more destructive way, such as behaving aggressively or bullying (Finkel and Vohs 2006).

- Sexual health one's coping skills and attitudes in romantic situations and relations (De Graaf et al. 2005).

- Social competence skills to successfully and positively interact with others in social situations (Shek and Leung 2016).

- School climate relationships among students and school staff within the school and behavioral norms, goals, and values that engender feelings of safety (Hopson et al. 2014).

- Aggression intentional, proactive or reactive, behavior intended to hurt. Others (Coyne et al. 2010).

- Bullying repeated, over time, exposure to negative actions (physical, verbal, or nonverbal) with the intention to hurt or bring discomfort upon another by one or more other individuals who are stronger (i.e., imbalance in strength; Olweus 1993).

\section{References}

\section{* Study included in the meta-analysis}

*Adler-Baeder, F., Kerpelman, J. L., Schramm, D. G., Higginbotham, B., \& Paulk, A. (2007). The impact of relationship education on adolescents of diverse backgrounds. Family Relations, 56, 291-303.

*Allara, E., Beccaria, F., Molinar, R., Marinaro, L., Ermacora, A., Coppo, A., et al. (2018). A school-based program to promote well-being in preadolescents: Results from a cluster quasi-experimental controlled study. The Journal of Primary Prevention, $40,151-170$.
*Ando, M., Asakura, T., Ando, S., \& Simons-Morton, B. (2007). A psychoeducational program to prevent aggressive behavior among Japanese early adolescents. Health Education \& Behavior, 34, 765-776.

Assink, M., \& Wibbelink, C. J. M. (2016). Fitting three-level metaanalytic models in R: A step-by-step tutorial. The Quantitative Methods for Psychology, 12, 154-174.

*Avery-Leaf, S., Cascardi, M., O’Leary, K. D., \& Cano, A. (1997). Efficacy of a dating violence prevention program on attitudes justifying aggression. Journal of Adolescent Health, 21, 11-17.

*Baker, C. K., Naai, R., Mitchell, J., \& Trecker, C. (2014). Utilizing a train-the-trainer model for sexual violence prevention: Findings from a pilot study with high school students of Asian and Pacific Islander descent in Hawai' i. Asian American Journal of Psychology, 5, 106-115.

Bakermans-Kranenburg, M. J., Van Ijzendoorn, M. H., \& Juffer, F. (2003). Less is more: Meta-analyses of sensitivity and attachment interventions in early childhood. Psychological Bulletin, $129,195-215$.

Barber, B. K. (2005). Positive interpersonal and intrapersonal functioning: An assessment of measures among adolescents. In K. A. Moore \& L. H. Lippman (Eds.), What do children need to flourish: Conceptualizing and measuring indicators of positive development (pp. 147-161). New York: Springer.

*Barkoukis, V., Lazuras, L., Ourda, D., \& Tsorbatzoudis, H. (2016). Tackling psychosocial risk factors for adolescent cyberbullying: Evidence from a school-based intervention. Aggressive Behavior, 42, 114-122.

*Bonell, C., Allen, E., Warren, E., McGowan, J., Bevilacqua, L., Jamal, F., et al. (2018). Effects of the learning together intervention on bullying and aggression in English secondary schools (INCLUSIVE): A cluster randomised controlled trial. Lancet, 392, 2452-2464.

*Bosworth, K., Espelage, D., DuBay, T., Daytner, G., \& Karageorge, K. (2000). Preliminary evaluation of a multimedia violence prevention program for adolescents. American Journal of Health Behavior, 24, 268-280.

*Boulton, M. J., \& Flemington, I. (1996). The effects of a short video intervention on secondary school pupils' involvement in definitions of and attitudes towards bullying. School Psychology, 17, 331-345.

Boustani, M. M., Frazier, S. T., Ecker, K. D., Bechor, M., Dinizulu, S. M., Hedemann, E. R., et al. (2015). Common elements of adolescent prevention programs: Minimizing burden while maximizing reach. Administration and Policy in Mental Health, 42, 209-219.

*Bradley, R. T., McCraty, R., Atkinson, M., Tomasino, D., Daugherty, A., \& Arguelles, L. (2010). Emotion self-regulation, psychophysiological coherence, and test anxiety: Results from an experiment using electrophysiological measures. Applied Psychophysiology and Biofeedback, 35, 261-283.

*Bull, H. D., Schultze, M., \& Scheithauer, H. (2009). School-based prevention of bullying and relational aggression: The fairplayer.manual. European Journal of Developmental Science, 3, 312-317.

*Burckhardt, R., Manicavasagar, V., Batterham, P. J., \& Hadzi-Pavlovic, D. (2016). A randomized controlled trial of strong minds: A school-based mental health program combining acceptance and commitment therapy and positive psychology. Journal of School Psychology, 57, 41-52.

*Burckhardt, R., Manicavasagar, V., Batterham, P. J., Hadzi-Pavlovic, D., \& Shand, F. (2017). Acceptance and commitment therapy universal prevention program for adolescents: A feasibility study. Child and Adolescent Psychiatry and Mental Health, 11, 27-36.

*Burckhardt, R., Manicavasagar, V., Shaw, F., Fogarty, A., Batterham, P. J., Dobinson, K., et al. (2018). Preventing mental health symptoms in adolescents using dialectical behaviour therapy skills 
group: A feasibility study. International Journal of Adolescence and Youth, 23, 70-85.

*Calear, A. L., Christensen, H., Mackinnon, A., Griffiths, K. M., \& O'Kearney, R. (2009). The YouthMood Project: A cluster randomized controlled trial of an online cognitive behavioral program with adolescents. Journal of Consulting and Clinical Psychology, 77, 1021-1032.

Campbell-Sills, L., \& Stein, M. B. (2007). Psychometric analysis and refinement of the Connor-Davidson Resilience Scale (CD-RISC): Validation of a 10-item measure of resilience. Journal of Traumatic Stress, 20(6), 1019-1028.

*Caplan, M., Weissberg, R. P., Grober, J. S., Sivo, P. J., Grady, K., \& Jacoby, C. (1992). Social competence promotion with inner-city and suburban young adolescents: Effects on social adjustment and alcohol use. Journal of Consulting and Clinical Psychology, 60, 56-63.

*Caprara, G. V., Kanacri, B. P. L., Gerbino, M., Zuffiano, A., Alessandri, G., Vecchio, G., et al. (2014). Positive effects of promoting prosocial behavior in early adolescence: Evidence from a school-based intervention. International Journal of Behavioral Development, 38, 386-396.

*Carraro, A., Gobbi, E., \& Moè, A. (2014). Brief report: Play fighting to curb self-reported aggression in young adolescents. Journal of Adolescence, 37, 1303-1307.

*Castillo-Gualda, R., Cabello, R., Herrero, M., Rodriguez-Carvajal, R., \& Fernandez-Berrocal, P. (2017). A three-year emotional intelligence intervention to reduce adolescent aggression: The mediating role of unpleasant affectivity. Journal of Research on Adolescence, 28, 186-198.

*Challen, A. R., Machin, S. J., \& Gillham, J. E. (2014). The UK Resilience Programme: A school-based universal nonrandomized pragmatic controlled trial. Journal of Consulting and Clinical Psychology, 82, 75-89.

*Chang, C., Tsai, G., \& Hsieh, C. (2013). Psychological, immunological and physiological effects of a Laughing Qigong Program (LQP) on adolescents. Complementary Therapies in Medicine, $21,660-668$.

*Cheung, C., \& Lee, T. (2010). Improving social competence through character education. Evaluation and Program Planning, 33, 255-263.

*Coelho, V. A., Marchante, M., \& Sousa, V. (2015). "Positive attitude": A multilevel model analysis of the effectiveness of a social and emotional learning program for Portuguese middle school students. Journal of Adolescence, 43, 29-38.

*Coker, A. L., Bush, H. M., Cook-Craig, P. G., DeGue, S. A., Clear, E. R., Brancato, C. J., et al. (2017). RCT testing bystander effectiveness to reduce violence. American Journal of Preventive Medicine, 52, 566-578.

*Connolly, J., Josephson, W., Schnoll, J., Simkins-Strong, E., Pepler, D., MacPherson, A., et al. (2015). Evaluation of a youth-led program for preventing bullying, sexual harassment, and dating aggression in middle schools. Journal of Early Adolescence, 35, 403-434.

*Constantine, N. A., Jerman, P., Berglas, N. F., Angulo-Olaiz, F., Chou, C., \& Rohrbach, L. A. (2015). Short-term effects of a rightsbased sexuality education curriculum for high-school students: A cluster-randomized trial. BMC Public Health, 15, 293-305.

Coyne, S. M., Nelson, D. A., \& Underwood, M. (2010). Aggression in children. In P. K. Smith \& C. H. Hart (Eds.), The Wiley-Blackwell handbook of childhood social development (pp. 491-509). Hoboken, New Jersey: Wiley.

Crocetti, E. (2016). Systematic reviews with meta-analysis: Why, when, and how? Emerging Adulthood, 4, 3-18.

*Cross, D., Shaw, T., Hadwen, K., Cardoso, P., Slee, P., Roberts, C., et al. (2016). Longitudinal impact of the Cyber Friendly
Schools program on adolescents' cyberbullying behavior. Aggressive Behavior, 42, 166-180.

Cuijpers, P. (2002). Effective ingredients of school-based drug prevention programs. A systematic review. Addictive Behaviors, 27, 1009-1023.

*Daly, L. A., Haden, S. C., Hagins, M., Papouchis, N., \& Ramirez, P. M. (2015). Yoga and emotion regulation in high school students: A randomized controlled trial. Evidence-Based Complementary and Alternative Medicine, 2015, 1-8.

De Graaf, H., Meijer, S., Poelman, J., \& Vanwesenbeeck, I. (2005). Seks onder je 25e [Sex under the age of 25]. Delft: Uitgeverij Eburon.

*De Graaf, I., De Haas, S., Zaagsma, M., \& Wijsen, C. (2016). Effects of rock and water: An intervention to prevent sexual aggression. Journal of Sexual Aggression, 22, 4-19.

De Mooij, B., Fekkes, M., Scholte, R. H. J., \& Overbeek, G. (2020). Effective components of Social Skills Training programs for children and adolescents in nonclinical samples: A multilevel meta-analysis. Clinical Child and Family Psychology Review, $23,250-264$.

*De Villiers, M., \& Van den Berg, H. (2012). The implementation and evaluation of a resiliency programme for children. South African Journal of Psychology, 42, 93-102.

De Vries, S. L. A., Hoeve, M., Assink, M., Stams, G. J. J. M., \& Asscher, J. J. (2015). Practitioner review: Effective ingredients of prevention programs for youth at risk of persistent juvenile delinquency - recommendations for clinical practice. Journal of Child Psychology and Psychiatry, 56, 108-121.

*Domino, M. (2013). Measuring the impact of an alternative approach to school bullying. The Journal of School Health, $83,430-437$.

Dray, J., Bowman, J., Campbell, E., Freund, M., Wolfenden, L., Hodder, R. K., et al. (2017). Systematic review of universal resilience-focused interventions targeting child and adolescent mental health in the school setting. Journal of the American Academy of Child and Adolescent Psychiatry, 56, 813-824.

Dufner, M., Gebauer, J. E., Sedikides, C., \& Denissen, J. J. A. (2019). Self-enhancement and psychological adjustment: A meta-analytic review. Personality and Social Psychology Review, 23, $48-72$.

*DuRant, R. H., Treiber, F., Getts, A., McCloud, K., Linder, C. W., \& Woods, E. R. (1996). Comparison of two violence prevention curricula for middle school adolescents. Journal of Adolescent Health, 19, 111-117.

Durlak, J. A., Weissberg, R. P., Dymnicki, A. B., Taylor, R. D., \& Schellinger, K. B. (2011). The impact of enhancing students' social and emotional learning: A meta-analysis of school-based universal interventions. Child Development, 82, 405-432.

Duval, S., \& Tweedie, R. (2000a). A nonparametric 'trim and fill' method of accounting for publication bias in meta-analysis. Journal of the American Statistical Association, 95, 89-99.

Duval, S., \& Tweedie, R. (2000b). Trim and Fill: A simple funnel-plot based method of testing and adjusting for publication bias in meta-analysis. Biometrics, 56, 455-460.

Egger, M., Smith, G. D., Schneider, M., \& Minder, C. (1997). Bias in meta-analysis detected by a simple, graphical test. BMJ, 315, 629-634.

*Espelage, D. L., Low, S., Polanin, J. R., \& Brown, E. C. (2013). The impact of a middle school program to reduce aggression, victimization, and sexual violence. Journal of Adolescent Health, $53,180-186$.

*Felver, J. C., Clawson, A. J., Morton, M. L., Brier-Kennedy, E., Janack, P., \& DiFlorio, R. A. (2018). School-based mindfulness intervention supports adolescent resiliency: A randomized 
controlled pilot study. International Journal of School \& Educational Psychology. https://doi.org/10.1080/21683603.2018.14617 22.

Ferguson, C. J., \& Brannick, M. T. (2012). Publication bias in psychological science: Prevalence, methods for identifying and controlling, and implications for the use of meta-analyses. Psychological Methods, 17, 120-128.

Finkel, E. J., \& Vohs, K. D. (2006). Introduction. Self and relationships. In K. D. Vohs \& E. J. Finkel (Eds.), Self and relationships: Connecting intrapersonal and interpersonal processes (pp. 1-9). New York: The Guilford Press.

*Foshee, V. A., Bauman, K. E., Ennett, S. T., Suchindran, C., Benefield, T., \& Linder, G. F. (2005). Assessing the effects of the dating violence prevention program "Safe dates" using random coefficient regression modeling. Prevention Science, 6, 245-258.

*Frank, J. L., Kohler, K., Peal, A., \& Bose, B. (2016). Effectiveness of a school-based yoga program on adolescent mental health and school performance: Findings from a randomized controlled trial. Mindfulness, 8, 544-553.

*Freire, T., Lima, I., Teixeira, A., Araujo, M. R., \& Machado, A. (2018). Challenge: To be+. A group intervention program to promote the positive development of adolescents. Children and Youth Services Review, 87, 173-185.

*Garaigordobil, M. (2004). Effects of a psychological intervention on factors of emotional development during adolescence. European Journal of Psychological Assessment, 20, 66-80.

*Garaigordobil, M. (2014). Effect of Cyberprogram 2.0 on reducing victimization and improving social competence in adolescence. Revista de Psicodidáctica, 19, 289-305.

*Garaigordobil, M., \& Martinez-Valderrey, V. (2015a). Effects of Cyberprogram 2.0 on "face-to-face" bullying, cyberbullying, and empathy. Psicothema, 27, 45-51.

*Garaigordobil, M., \& Martinez-Valderrey, V. (2015b). The effectiveness of Cyberprogram 2.0 on conflict resolution strategies and self-esteem. Journal of Adolescent Health, 57, 229-234.

*Gardner, S. P., Giese, K., \& Parrott, S. M. (2004). Evaluation of the connections: Relationships and marriage curriculum. Family Relations, 53, 521-527.

*Ghahremani, D. G., Oh, E. Y., Dean, A. C., Mouzakis, K., Wilson, K. D., \& London, E. D. (2013). Effects of the youth empowerment seminar on impulsive behavior in adolescents. Journal of Adolescent Health, 53, 139-141.

*Giannotta, F., Settanni, M., Kliewer, W., \& Ciairano, S. (2009). Results of an Italian school-based expressive writing intervention trial focused on peer problems. Journal of Adolescence, 32, $1377-1389$

*Gigantesco, A., Del Re, D., Cascavilla, I., Palumbo, G., De Mei, B., Cattaneo, C., et al. (2015). A universal mental health promotion programme for young people in Italy. BioMed Research International, 2015, 1-10.

Gilman, R., \& Anderman, E. M. (2006). The relationship between relative levels of motivation and intrapersonal, interpersonal, and academic functioning among older adolescents. Journal of School Psychology, 44, 375-391.

Girard, J. M., Wright, A. G. C., Beeney, J. E., Lazarus, S. A., Scott, L. N., Stepp, S. D., et al. (2017). Interpersonal problems across levels of the psychopathology hierarchy. Comprehensive Psychiatry, 79, 53-69.

*Gollwitzer, M., Banse, R., Eisenbach, K., \& Naumann, A. (2007). Effectiveness of the Vienna Social Competence Training on explicit and implicit aggression: Evidence from an Aggressiveness-IAT. European Journal of Psychological Assessment, 23, $150-156$.

*Gouda, S., Luong, M. T., Schmidt, S., \& Bauer, J. (2016). Students and teachers benefit from mindfulness-based stress reduction in a school-embedded pilot study. Frontiers in Psychology, 7, 590-607.

*Hains, A. A. (1994). The effectiveness of a school-based, cognitivebehavioral stress management program with adolescents reporting high and low levels of emotional arousal. School Counselor, $42,114-125$

*Hains, A. A., \& Ellmann, S. W. (1994). Stress inoculation training as a preventative intervention for high school youths. Journal of Cognitive Psychotherapy: An International Quarterly, 8, 219-232.

*Hains, A. A., \& Szyjakowski, M. (1990). A cognitive stress-reduction intervention program for adolescents. Journal of Counseling Psychology, 37, 79-84.

*Haynes, L. A., \& Avery, A. W. (1979). Training adolescents in selfdisclosure and empathy skills. Journal of Counseling Psychology, 26, 526-530.

Hedges, L. (1983). A random effects model for effect sizes. Psychological Bulletin, 93, 388-395.

Hennessy, E. A., \& Tanner-Smith, E. E. (2015). Effectiveness of brief school-based interventions for adolescents: A meta-analysis of alcohol use prevention program. Prevention Science, 16, 463-474.

Higgins, J. P. T., Sterne, J. A. C., Savović, J., Page, M. J., Hróbjartsson, A., Boutron, I., et al. (2016). A revised tool for assessing risk of bias in randomized trials. Cochrane Database of Systematic Reviews, 10(Suppl 1), 29-31. https://doi.org/10.1002/14651858. CD201601.

Hopson, L. M., Schiller, K. S., \& Lawson, H. A. (2014). Exploring linkages between school climate, behavioral norms, social supports, and academic success. Social Work Research, 38, 197-209.

*Horn, A. B., Pössel, P., \& Hautzinger, M. (2010). Promoting adaptive emotion regulation and coping in adolescence: A school-based programme. Journal of Health Psychology, 16, 258-273.

Horne, A. M., Stoddard, J. L., \& Bell, C. D. (2007). Group approaches to reducing aggression and bullying in school. Group Dynamics. Theory, Research, and Practice, 11, 262-271.

*Huppert, F. A., \& Johnson, D. M. (2010). A controlled trial of mindfulness training in schools: The importance of practice for an impact on well-being. The Journal of Positive Psychology, 5, 264-274.

*Ingram, K. M., Espelage, D. L., Merrin, G. J., Valido, A., Heinhorst, J., \& Joyce, M. (2019). Evaluation of a virtual reality enhanced bullying prevention curriculum pilot trial. Journal of Adolescence, $71,72-83$.

*Jaycox, L. H., McCaffrey, D., Eiseman, B., Aronoff, J., Shelley, G. A., Collins, R. L., et al. (2006). Impact of a school-based dating violence prevention program among Latino teens: Randomized controlled effectiveness trial. Journal of Adolescent Health, 39, 694-704.

*Jiménez-Barbero, J. A., Ruiz-Hernández, J. A., Llor-Zaragoza, L., Pérez-Garcia, M., \& Llor-Esteban, B. (2016). Effectiveness of anti-bullying school programs: A meta-analysis. Children and Youth Services Review, 61, 165-175.

Kaminski, J. W., Valle, L. A., Filene, J. H., \& Boyle, C. L. (2008). A meta-analytic review of components associated with parent training program effectiveness. Journal of Abnormal Child Psychology, 36, 567-589.

Karoly, P. (1993). Mechanisms of self-regulation: A systems view. Annual Review of Psychology, 44, 23-52.

*Kasler, J., White, G. W., \& Elias, M. J. (2013). Evaluation of the Meaning of Life program in Israel. Peabody Journal of Education, 88, 243-260.

*Kaveh, M. H., Hesampour, M., Ghahremani, L., \& Tabatabaee, H. R. (2014). The effects of a peer-led training program on female students' self-esteem in public secondary schools in Shiraz. Journal of Advances in Medical Education \& Professionalism, 2, 63-70. 
*Khanna, P., \& Singh, K. (2016). Effect of gratitude educational intervention on well-being indicators among North Indian adolescents. Contemporary School Psychology, 20, 305-314.

*Kiselica, M. S., Baker, S. B., Thomas, R. N., \& Reedy, S. (1994). Effects of stress inoculation training on anxiety, stress, and academic performance among adolescents. Journal of Counseling Psychology, 41, 335-342.

*Klingman, A., \& Hochdorf, Z. (1993). Coping with distress and self harm: The impact of a primary prevention program among adolescents. Journal of Adolescence, 16, 121-140.

Kobak, K. A., Wolitzky-Taylor, K., Craske, M. G., \& Rose, R. D. (2017). Therapist training on Cognitive Behavior Therapy for anxiety disorders using internet-based technologies. Cognitive Therapy and Research, 41, 252-265.

*Kozina, A. (2018a). Can the "my friends" anxiety prevention programme also be used to prevent aggression? A six-month followup in a school. School Mental Health, 10, 500-509.

*Kozina, A. (2018b). School-based prevention of anxiety using the "My FRIENDS" emotional resilience program: Six-month follow-up. International Journal of Psychology. https://doi. org/10.1002/ijop.12553.

*Lamke, L. K., Lujan, B. M., \& Showalter, J. M. (1988). The case for modifying adolescents' cognitive self-statements. Adolescence, 23, 967-974.

Landis, J. R., \& Koch, G. G. (1977). The measurement of observer agreement for categorical data. Biometrics, 33, 159-174.

Langford, R., Bonell, C. P., Jones, H. E., Pouliou, T., Murphy, S. M., Waters, E., et al. (2014). The WHO Health Promoting School framework for improving the health and well-being of students and their academic achievement. The Cochrane Databased of Systematic Reviews. https://doi.org/10.1002/14651858.CD008 958.pub2.

Lee, B. R., Ebesutani, C., Kolivoski, K. M., Becker, K. D., Lindsey, M. A., Brandt, N. E., et al. (2014). Program and practice elements for placement prevention: A review of interventions and their effectiveness in promoting home-based care. American Journal of Orthopsychiatry, 84, 244-256.

Light, R., \& Pillemer, D. (1984). Summing up: The science of reviewing research. Cambridge: Harvard University Press.

Lipsey, M. W., \& Wilson, D. B. (2001). Practical meta-analysis. Thousand Oaks, CA: Sage Publications.

* Macgowan, M. J. (1997). An evaluation of a dating violence prevention program for middle school students. Violence and Victims, 12, 223-235.

*Menesini, E., Codecasa, E., Benelli, B., \& Cowie, H. (2003). Enhancing children's responsibility to take action against bullying: Evaluation of a befriending intervention in Italian middle schools. Aggressive Behavior, 29, 1-14.

*Miller, S., Williams, J., Cutbush, S., Gibbs, D., Clinton-Sherrod, M., \& Jones, S. (2015). Evaluation of the Start Strong initiative: Preventing teen dating violence and promoting healthy relationships among middle school students. Journal of Adolescent Health, 56, S14-S19.

Modecki, K. L., Zimmer-Gembeck, M. J., \& Guerrà, N. (2017). Emotion regulation, coping, and decision making: Three linked skills for preventing externalizing problems in adolescence. Child Development, 88, 417-426.

*Muck, C., Schiller, E., Zimmermann, M., \& Kartner, J. (2018). Preventing sexual violence in adolescence: Comparison of a scientist-practitioner program and a practitioner program using a cluster-randomized design. Journal of Interpersonal Violence. https://doi.org/10.1177/0886260518755488.

Mychailyszyn, M. P., Brodman, D. M., Read, K. L., \& Kendall, P. C. (2012). Cognitive-behavioral school-based interventions for anxious and depressed youth: A meta-analysis of outcomes. Clinical Psychology, Science and Practice, 19, 129-153.
*Nash, K. A. (2007). Implementation and evaluation of the empower youth program. Journal of Holistic Nursing, 25, 26-36.

*Noggle, J. J., Steiner, N. J., Minami, T., \& Khalsa, S. B. S. (2012). Benefits of yoga for psychosocial well-being in a US high school curriculum: A preliminary randomized controlled trial. Journal of Developmental and Behavioral Pediatrics, 33, 193-201.

Olweus, D. (1993). Bullying at school: What we know and what we can do. Oxford: Blackwell Publishers.

Onrust, S. A., Otten, R., Lammers, J., \& Smit, F. (2016). School-based programmes to reduce and prevent substance use in different age groups: What works for whom? Systematic review and metaregression analysis. Clinical Psychology Review, 44, 45-59.

*Orpinas, P., Parcel, G. S., McAlister, A., \& Frankowski, R. (1995). Violence prevention in middle schools: A pilot evaluation. Journal of Adolescent Health, 17, 360-371.

*Ortega-Baron, J., Buelga, S., Ayllon, E., Martinez-Ferrer, B., \& Cava, M. (2019). Effects of intervention program Prev@cib on traditional bullying and cyberbullying. International Journal of Environmental Research and Public Health, 16, 527-539.

*Pacifici, C., Stoolmiller, M., \& Nelson, C. (2001). Evaluating a prevention program for teenagers on sexual coercion: A differential effectiveness approach. Journal of Consulting and Clinical Psychology, 69, 552-559.

Park, D., Tsukayama, E., Goodwin, G., Patrick, S., \& Duckworth, A. L. (2017). A tripartite taxonomy of character: Evidence for intrapersonal, interpersonal, and intellectual competencies in children. Contemporary Educational Psychology, 48, 16-27.

Pellegrino, J. W., \& Hilton, M. L. (2012). Education for life and work: Developing transferable knowledge and skills in the 21st century. Washington, DC: National Academy of Sciences.

Peters, L. W. H., Kok, G., Ten Dam, G. T. M., Buijs, G. J., \& Paulussen, T. G. W. M. (2009). Effective elements of school health promotion across behavioral domains: A systematic review of reviews. BMC Public Health, 9, 182-196.

Petty, C. R., Rosenbaum, J. R., Hirshfeld-Becker, D. R., Henin, A., Hubley, S., LaCasse, S., et al. (2008). The Child Behavior Checklist broad-band scales predict subsequent psychopathology: A five-year follow-up. Journal of Anxiety Disorders, 22, 532-539.

Poulin, F., Dishion, T. J., \& Burraston, B. (2001). 3-year iatrogenic effects associated with aggregating high-risk adolescents win cognitive-behavioral preventive interventions. Applied Developmental Science, 5, 214-224.

PracticeWise. (2009). Psychosocial and combined treatments coding manual. Satellite Beach, FL: PracticeWise.

*Proctor, C., Tsukayama, E., Wood, A. M., Maltby, J., Fox Eades, J., \& Linley, P. A. (2011). Strengths Gym: The impact of a character strengths-based intervention on the life satisfaction and well-being of adolescents. The Journal of Positive Psychology, $6,377-388$.

*Richardson, S. M., Paxton, S. J., \& Thomson, J. S. (2009). Is BodyThink an efficacious body image and self-esteem program? A controlled evaluation with adolescents. Body Image, 6, 75-82.

Robitail, S., Ravens-Sieberer, U. R., Simeoni, M., Rajmil, L., Bruil, J., Power, M., et al. (2007). Testing the structural and cross-cultural validity of the KIDSCREEN-27 quality of life questionnaire. Quality of Life Research, 16, 1335-1345.

*Ruini, C., Belaise, C., Brombin, C., Caffo, E., \& Fava, G. A. (2006). Well-being therapy in school cettings: A pilot study. Psychotherapy and Psychosomatics, 75, 331-336.

*Ruini, C., Ottolini, F., Tomba, E., Belaise, C., Albieri, E., Visani, D., et al. (2009). School intervention for promoting psychological well-being in adolescence. Journal of Behavior Therapy and Experimental Psychiatry, 40, 522-532.

*Ruiz-Aranda, D., Castillo, R., Salguero, J. M., Cabello, R., FernándezBerrocal, P., \& Balluerka, N. (2012). Short- and midterm effects 
of emotional intelligence training on adolescent mental health. Journal of Adolescent Health, 51, 462-467.

*Sanchez-Jimenez, V., Munoz-Fernandez, N., \& Ortega-Rivera, J. (2018). Efficacy evaluation of "Dat-e Adolescence": A dating violence prevention program in Spain. PLoS ONE, 13, e0205802.

*Schramm, D. G., \& Gomez-Scott, J. (2012). Merging relationship education and child abuse prevention knowledge: An evaluation of effectiveness with adolescents. Marriage and Family Review, 48, 792-808.

*Schultz, L. H., Barr, D. J., \& Selman, R. L. (2001). The value of a developmental approach to evaluating character development programmes: An outcome study of Facing History and Ourselves. Journal of Moral Education, 30, 3-27.

Shek, D. T. L., \& Leung, J. T. Y. (2016). Developing social competence in a subject on leadership and intrapersonal development. International Journal on Disability and Human Development, $51,165-173$.

*Shek, D. T. L., \& Ma, C. M. S. (2011). Impact of the Project P.A.T.H.S. in the junior secondary school years: Individual growth curve analyses. The Scientific World Journal, 11, 253-266.

*Shinde, S., Weiss, H. A., Varghese, B., Khandeparkar, P., Pereira, B., Sharma, A., et al. (2018). Promoting school climate and health outcomes with the SEHER multi-component secondary school intervention in Bihar, India: A cluster-randomised controlled trial. Lancet, 392, 2465-2477.

*Shoshani, A., \& Steinmetz, S. (2014). Positive psychology at school: A school-based intervention to promote adolescents' mental health and well-being. Journal of Happiness Studies, 15, 1289-1311.

*Sibinga, E. M. S., Perry-Parrish, C., Chung, S., Johnson, S. B., Smith, M., \& Ellen, J. M. (2013). School-based mindfulness instruction for urban male youth: A small randomized controlled trial. Preventive Medicine, 57, 799-801.

*Simons-Morton, B., Haynie, D., Saylor, K., Crump, A. D., \& Chen, R. (2005). The effects of the Going Places Program on early adolescent substance use and antisocial behavior. Prevention Science, 6, 187-197.

*Soliday, E., Garofalo, J. P., \& Rogers, D. (2004). Expressive writing intervention for adolescents' somatic symptoms and mood. Journal of Clinical Child and Adolescent Psychology, 33, 792-801.

*Solomontos-Kountouri, O., Gradinger, P., Yanagida, T., \& Strohmeier, D. (2016). The implementation and evaluation of the ViSC program in Cyprus: Challenges of cross-national dissemination and evaluation results. European Journal of Developmental Psychology, 13, 737-755.

*Sorrentino, A., Baldry, A. C., \& Farrington, D. (2018). The efficacy of the Tabby Improved prevention and intervention program in reducing cyberbullying and cybervictimization among students. International Journal of Environmental Research and Public Health, 15, 2536-2549.

*Stevens, V., Bourdeaudhuij, I., \& Oost, P. (2000). Bullying in Flemish schools: An evaluation of anti-bullying intervention in primary and secondary schools. British Journal of Educational Psychology, 70, 195-210.

*Thomaes, S., Bushman, B. J., Orobio de Castro, B., Cohen, G. L., \& Denissen, J. J. A. (2009). Reducing narcissistic aggression by buttressing self-esteem: An experimental field study. Psychological Science, 20, 1536-1542.

*Thompkins, A. C., Chauveron, L. M., Harel, O., \& Perkins, D. F. (2014). Optimizing violence prevention programs: An examination of program effectiveness among urban high school students. The Journal of School Health, 84, 435-443.

*Tomyn, J. D., Fuller-Tyszkiewicz, M., Richardson, B., \& Colla, L. (2016). A comprehensive evaluation of a universal school-based depression prevention program for adolescents. Journal of Abnormal Child Psychology, 44, 1621-1633.

*Trip, S., Bora, C., Sipos-Gug, S., Tocai, I., Gradinger, P., Yanagida, T., et al. (2015). Bullying prevention in schools by targeting cognitions, emotions, and behavior: Evaluating the effectiveness of the REBE-ViSC program. Journal of Counseling Psychology, $62,732-740$.

Ttofi, M. M., \& Farrington, D. P. (2011). Effectiveness of school-based programs to reduce bullying: A systematic and meta-analytic review. Journal of Experimental Criminology, 7, 27-56.

*Tunariu, A. D., Tribe, R., Frings, D., \& Albery, I. P. (2017). The iNEAR programme: An existential positive psychology intervention for resilience and emotional wellbeing. International Review of Psychiatry, 29, 362-372.

Van den Noortgate, W., López-López, J. A., Marín'Martínez, F., \& Sánchez-Meca, J. (2013). Three-level meta-analysis of dependent effect sizes. Behavior Research Methods, 45, 576-594.

*Van der Meulen, K., Granizo, L., \& del Barrio, C. (2010). Using EQUIP for educators to prevent peer victimization in secondary school. Journal of Research in Character Education, 8, 61-76.

Van der Put, C. E., Assink, M., Gubbels, J., \& Boekhout van Solinge, N. F. (2018). Identifying effective components of child maltreatment interventions: A meta-analysis. Clinical Child and Family Psychology Review, 21, 171-202.

Van Orden, K., Wingate, L. R., Gordon, K. H., \& Joiner, T. E. (2005). Interpersonal factors as vulnerability to psychopathology over the life course. In B. L. Hankin \& J. R. Z. Abela (Eds.), Development of psychopathology: A vulnerability-stress perspective. Thousand Oaks, CA: Sage Publications.

*Van Schoiack-Edstrom, L., Frey, K. S., \& Beland, K. (2002). Changing adolescents' attitudes about relational and physical aggression: An early evaluation of a school-based intervention. School Psychology Review, 31, 201-216.

Viechtbauer, W. (2010). Conducting meta-analyses in R with the metafor package. Journal of Statistical Software, 36, 1-48.

Weisz, J. R., Chorpita, B. F., Palinkas, F. A., Schoenwald, S. K., Miranda, J., Bearman, S. K., et al. (2012). Testing standard and modular designs for psychotherapy treating depression, anxiety, and conduct problems in youth. Archives of General Psychiatry, 69, 274-282.

Werch, C. E., \& Owen, D. M. (2002). Iatrogenic effects of alcohol and drug prevention programs. Journal of Studies on Alcohol and Drugs, 63, 581-590.

White, B. A., Jarrett, M. A., \& Ollendick, T. H. (2013). Self-regulation deficits explain the link between reactive aggression and internalizing and externalizing behavior problems in children. Journal of Psychopathology and Behavioral Assessment, 35, 1-9.

Wichstraum, L. (1995). Harter's self-perception profile for adolescents: Reliability, validity, and evaluation of the question format. Journal of Personality Assessment, 65, 100-116.

*Williams, J., Miller, S., Cutbush, S., Gibbs, D., Clinton-Sherrod, M., \& Jones, S. (2015). A latent transition model of the effects of a teen dating violence prevention initiative. The Journal of Adolescent Health, 56, S27-S32.

*Williford, A., Elledge, L. C., Boulton, A. J., DePaolis, K. J., Little, T. D., \& Salmivalli, C. (2013). Effects of the KiVa antibullying program on cyberbullying and cybervictimization frequency among Finnish youth. Journal of Clinical Child and Adolescent Psychology, 42, 820-833.

*Wong, D. S. W., Cheng, C. H. K., Ngan, R. M. H., \& Ma, S. K. (2011). Program effectiveness of a Restorative Whole-school Approach for tackling school bullying in Hong Kong. International Journal of Offender Therapy and Comparative Criminology, 55, 846-862. 
World Health Organization. (1997). Life skills education in schools. Geneva: WHO/MNH/PSF/93.7A. Rev. 2.

World Health Organization. (1995). Global school health initiative. Retrieved from https://www.who.int/school_youth_health/gshi/ en/. Accessed May 2019.

*Yanagida, T., Strohmeier, D., \& Spiel, C. (2019). Dynamic change of aggressive behavior and victimization among adolescents: Effectiveness of the ViSC Program. Journal of Clinical Child and Adolescent Psychology, 48, S90-S104.

Yeager, D. S., \& Walton, G. M. (2011). Social-psychological interventions in education: They're not magic. Review of Educational Research, 81, 267-301.
*Yom, Y., \& Eun, L. K. (2005). Effects of a CD-ROM educational program on sexual knowledge and attitude. Computers, Informatics, Nursing, 23, 214-219.

Yovel, I., Mor, N., \& Shakarov, H. (2014). Examination of the core cognitive components of Cognitive Behavioral Therapy and Acceptance and Commitment Therapy: An analogue investigation. Behavior Therapy, 45, 482-494.

Publisher's Note Springer Nature remains neutral with regard to jurisdictional claims in published maps and institutional affiliations. 